University of Massachusetts Amherst

ScholarWorks@UMass Amherst

Masters Theses 1911 - February 2014

1933

\title{
What is a progressive school?
}

Andrew Anderson

University of Massachusetts Amherst

Follow this and additional works at: https://scholarworks.umass.edu/theses

Anderson, Andrew, "What is a progressive school?" (1933). Masters Theses 1911 - February 2014. 1284. Retrieved from https://scholarworks.umass.edu/theses/1284

This thesis is brought to you for free and open access by ScholarWorks@UMass Amherst. It has been accepted for inclusion in Masters Theses 1911 - February 2014 by an authorized administrator of ScholarWorks@UMass Amherst. For more information, please contact scholarworks@library.umass.edu. 
UMASS/AMHERST

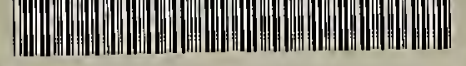

ヨ12066013577024

WHAT IS A PROGRESSWV SCHOOL

ANDERSON- 1933 

WHAT IS A PROGRES'SIVA SCHOOL?

by

Androw Andorgon

Thesis submitted for dogreo of hioster of Scionco

Ilossachusette Stato Collogo

Amherst, riass.

1933. 


\section{IIITRODUCTAOH.}

A quick survoy of the curront periodicals, oducational and othorwise, will indicate that tho progressive gchool novemont is tho curront topic of aiscussion with regerd to caucation. It will indicato without question thet tho subject is a highly controvorgal ono. It will indicato, too, that important mon within the fiold of oducation have taken sides definitoly for and acingt.

Why all this interost? What is thoro controvorsel about it? Why havo our looding ocucators so dofinitoly telien sides? In othor words, whot is the progressive school movement? that is a progressive school?

It sooms thet tho logical first stop in an inquiry of this kind is to aramine tho past to soo whethor or not tho progresaivo school movemont has a hictorical backsround, th.t is, to soe whothor or not so can find in tho literaturo of the pust few conturios tho samo sort of thing that progressive oductors are talling about today. If tho answor is in the affimotive, it would obviously lond an ontiroly differont cepoct to tho wholo subject. It would be cios r thet tho movemont is not a now idea, not a fad, and thus would be descrping of a more maspoctint attontiun. This, thon, is the first gtop.

The second stop, it socms, would follow logically. It would bo an examination of tho presont and immodiate past to 
discover the developrent and present proportions of the movemont. If we find that it has attracted the active interest of a large number of poople throughout the world wo will be likeIy to conclude the.t there is undoubtedy something embodied within the movoment worthy of our interest. This, then, is the second stop.

The third and last step is an exanination of the ejucational principlos within the movement. The oducational principles of such leaders in the progressive school movement as Maria Montessori, John Dowey, Helen Parkhurst and Carleton Washburne will be pointed out, compared and critically ezaminod, as far as possible, with rogard to elomentary public school experience. The wide dirorgity of method among individual progressive schools will bo pointed out and discussod. Finally, the "bug-boar" of the progressive school and the crux of the wholo idea underlying prosrossive oducation--interestwill be discussed and some methods pointed out which have becn used in tho attempt to stimulato natural interest in tho child for school work.

Since most progressive schools include only the first eight grados and since those that do incluãe high school nust, of necessity forogo most of their progressive principlos whilo educating high school students because of the necessity of preparing for the "traditionel" college entranco eraminations, this papor will be devoted to those aspects of progrossive education which are pertinent to the elementary grades. 
The Philosophical Background of Progrossive Education. In examing the past it is found invariably that, when a group of people are not in symathy with an oxisting forn of social organization or prodedure, thoy assert thomsolves in one or more of the following ways:

1. They talk and write about tho deficiencies or the evils; or the specific effects or the general tendoncies of the thing with which they are in aisagreoment; they discues present conditions in comparicon with past conditions; they project other plans of organization or proceduro that soem rore promising. An oramination of the current books, poriodicals and nevspapors makes this point obviously true.

2. They ignore the existing social form and sot un their own. Hartin Iuthor ana his ahorents rebelled against the ezcessivo burden of tazation imposed by the Roman Catholic Church and sot up their om church. Tho Southorn States attempted to socode from the Union and set up their own govornment because thoy felt thet the northern stateg were usurping political pover and that the Fedoral govornment vas usurping states rights.

3. They attack directy tho oxidting socisl form with which they are in disagreomont. This mothod is followed, usualy, when it is not impossible to ignore the existing form. Wo havo an oxamplo of this procoduro at present in regkrd to the dightoenth Amendment of our 
Constitution. Since it is a national law, the peoplo have no legal recourse but to observe it. Tho only way thoy may manifost an active form of rebelilon, if they foel so inclined, is to attack it directly and try to obliterato it. An attempt is being made in that diroction now.

In the same vay the Progressive School movement is a revolt against tho organization and procedure involved in ono of our social institutions--the public school. In general it concerns itsolf with the first two forns of rebollion noted. The vocal oxpononts of the movement havo talkod and written about it, and the progressive schools of verving forms have sprung up throughout the country and world, ignoring the methods and standards of the treditional schools, insorting instead their own mothods and standerds. Detormination of tho latter, and, particularly, the principles underlying them, will be tho main purpose of this thesis. In regara to tho formor, as steted, thore has boen a tremendous amount witten. Carleton Washburne and Iyson stoarns, co-authors of "Better Schools" say, concocning our public schools and the noed of a change in our educational mothods:

"But here and there, the country over, indopendont thinkors Inside the acadomic field as vell as outside are beginning to query searchingly the efficacy to date of our entire great educational experiment."

"From the standpoint of giving a tolerably good gresp of the thrce R's and somo acadomic knovlodso, our schools certainly 
aro not failures. They give, in general, pretty good schooling. But from the standpoint of what they might give if children are to have a real chance to Iive and develop fully, and if the best parts of our civilization are to survive, most schools may well be considored failures."

Spocificelly, the rovolt against the methods genorally in use in the traditional schools rests on two points.

1. It is a protest against a mothod which involvos toaching a group of children of approximately the seme ago a definite anount of material in a definite period of tine.

2. It is a protest against the tocinicue of the class-room, the dominating attitude of tho teacher and the restricted freodon of the children.

Regarding the rirst point, scientific inquiry has substantiatod the age old conviction that montal and moral characteristics very as do physical charactoristics; and bocsuso of these indiviaual afferences, progressive educators bolieve that it is impogible to troat all chilaren of the game chronological age in the same namner.

Carloton Vashburne says in "Adju ting the School to tho Child:" (2)

"Wo know that almost any so-celled fourth grade contains children of second, third, fourth, fifth and sixth grade ability in any subjoct wo wish to test and that renge is equally groat in all othor grados of tho school syster. To 
troat chilaren whose abilities range through four or five grades as if thoy wore aliko, siving them all the same ascignmont and the same tine to accomplish thet esgignment and thon marking them all by a common standard is so propostorous in the light of prosent day lnovlodge that every one is looking for a romody to the situation."

Anent the second general protest of progressive oducation against the traditional school, John Dowoy hos this to say in "My Yedagogical Croed:"

"The teacher is not in the school to imposo certain ideas or form cortain habits in the child, but is thore as a mombor of the commity to select the influences which will o.fect the child and to assist hin in proporly rosponding to these inPlvences."

Dowey id attacking, indirecty, the dominativo and authritative attitude of the teacher in tho traditional school when he says that the teacher must not inpose "certain ideas or form cortain habits in the chila."

We must not assumo that these protests aro recont, that thoy have taken shape during the last two or three generations. An examination of history makes it clear that these protosts originstod as oarly as tho sixteonth century. For the sake of perspective, and, to show that strong philosophic support underlios these current protests of progrossive oducators, an exanination of the past is ossential.

Francis Rabolais (1483-1553) wo: "a trenchent satirict in the humanistic tondoncios and the le rnino of his time. His 
great work consisted in combatting the formal, insincere, shallow Iifo of the poriod, whethur in state or church or school." (4)

Rabelais attackod the fromal literary oducation of his time and wished to substituto one which includou sooial, moral, religious and physical elemonte. "Studios vore to bo made pleasant; games and sports woro to be used for this purpose as well as for their usefulness in the physical development of the child and for thoir practical boaring on his duties later in lifo." (5)

In his "Garsentus," Rabelais Eives, specifically, his conception of what olucetion should be. Book loarning, including Iatin, German, Hnglish, Spanish, rhotoric and arithmetic wore essontial. Ho adrocated sports of all kinds. A mastery of the natural scionces was to be obtainod through the writings of recognized authoritios of his timo and by direct study and ossorvation of nature. A portion of Gorcantua's daily study was to be done in the woods and rields where the phenomena of nature moula be laia airectly bofore his eyes.

The oducational methods advocated by Rabelais are not radical in viou of present dey thought. Hig bitter satire led him to exrggoration ofton tiros and boceuse of that oxagjeration ho apnears radical. For instance the pexformance through which ho pute Gargantua in one day (7) is more than we world expect of a child today. But Gareantue vas a gient. His pirysiuno was such that ho could rise at four o'clock in the morn- 
ing and romp through his studios and sports at a marvolous pace. A moderate doso of the same thing moro in accordance vith tho staturo of the average boy or girl would not soem to us very much out of placo.

But of courso in his timo he vas extromoly realcal. The narrow clasgical adncetors of the sixteonth contury who looked upon tho study of tho classical langragos and litorature as the sole moans to un education, lookod on Rabolais mith horror. inichol de lontaigno, (1553-1592) who showed tho influcneos of Rabolals vory strongly, gavo vent to his protests against the formal eurcation of his day in his ossay on "The dacation of Chilaron."

Thile Rabolais made no roforonce to the importance of recosniming individual alforonces in childron, Montaigne was very definito thorein.

"Such as according to our common way of teachine, undortako, with one and the sane losson, and tho samo mossure of diroction, to instruct soveral boye of difforent end unequal capecitios aro 1ucinitely mistaken in thoir mothoã....." (8) As early a 1588 liontajuno had rocognized tho i.portanoo of tho vory ting around winch Dovoy, Washumno and other progressive ouncators build thoir educational theorios.

In anothor part of "The iducation of Childron", lontaigno attackod tho formalism of the clossrom and tho dominating attitude of tho teachor in much the sano mannor that vocal exponents of prozrosgive olucation are doing today. 
wis tho custom of schoolmasters to bo otornally thundorins in thoir pupils' oars, as thoy were pouring into a fumel whilst their business is only to repoat wh the othorg have said beforo: How I would havo a tutor to correct tisis error, and thet at tho very first ho chould, according to tho capacity ho has to deal with, put it to tho test, pormitting his pupil himeeli to tasto and rolish things, ond of himself to chooso and discem thom, somotinos oponing the wey to him, cnd somoti. 0 losving hin to brosk tho lco hincolf." (9)

Thus wo see thet liontaigne'g proteste ageinst tho educational mothods of his ary aro oscontially tho sane ss the protocts of progressive ecucators or todey.

Joon Jrcquos Roussoar $(2712-78)$ also can the futility of attompting to elucato the child without studying the child to find his oeneoitios and limitations. I quoto from is "แnilo:"

"kor countless gonerations there hes boon a peremial protost against tho ourront practico but no ono has soen fit to prepare a bottor. Tho Iiterature and lo rning of our contury tend mach nore to destroy then to construct. Wo do not Inow chilahood. Scting on the folso idces ve have of it, tho furthor vo go, the firther wo vandor from the ri ht path. Whose who aro wisost nro attached to what is inportant for mon to lnow vithout considering whit childron are able to comprohond.....Bogin, thon, by studying jour punils noro thoroujing for it is very cortain thut jou do not know thom." (IC) 
Roussoau had no sympethy for tho aevoro discinlino of the classroom and the dominating attitudo of tho toacher. In his "Emilo" ho pointod out thet the child shold nover find roaistence in vills, only in things. In the pollovins quotation from "Hmile" Roussoou exprossod Dovoy's idoc rojuraing the poation of the toachor in tho clessroom:

"rry an opposite courso with your punil. While you roally covern, lot in alco fency that he is tho mestor. Where is no subjoction so porfoct as that which preserves tho apposrance of liberty. Doubtloss your pupil ought to do only what he chooses but he ought to choose only th $t$ you wish to have hin (40." (II)

John Ioclio $(1652-1704)$ expressod the sano ides in "Some Thoujhts Concdming Laucetion:"

"I told you boioro that chilaron lovo I1boity and therofore thoy sirovid bo vroujht to dio tho things thot ere fit for thon without fooling ay restraint laid on them."

Rousceau thus found the samo shortcomins in tho oducational nothods of his day thet nodorn progroseivo oủncators find in tho modorn traditional school.

Johamn Hoinrlah Fostalozzi (1746-1827) is comonly callod tho "father" of ous puilic school syston of o. ucction and is not sonorally reforron to wo ono of tho philosopical originatorg or promessivo oducation.

Horace llam, whilo socrotary of tho nowly formed state Bo: ra of tauc tion in llascechusote visited turopo in 1845 
and camo back full of praise for the Gormen and Dutch schools which followed Postalozi's principlos of odveation. (12) Howovor, his attompt to introduco somo of theso mothods into tho public schools of lassachusotts mot with suddon and violent protost which rosultod in his fanous controvergy with the Boston schoolnastors. Ifom won and introduced a number of reforms pattornod artor pestalozzi but just hov far ho missed his merk will be soon by a brief orchination of Postalozic's principlos.

It hos boon said previously thet Progroseivo oduc tors do not rocognize Postalozi as ono of thoir group. Hyrick makos this evidont when he says in his "Progressive Lacetion:"

"In eaucetion we do not nood to look back far into the pest to find Postalozzianlsm..... ond Innumercule othor syctens and isms, some of wich are still with ve ond have more or loss voguo, although an evidontly doclining vogro."

But on closor inspoction of Postalozis wo find him in wroenent with progrossive oduc tors at the two vital points, indiviaual attontion to the child, end inepiration and guidano rethor than domination on the pert of the teacher.

Postalocal makos no postivo statemont rocerding the importance of rocosnizing individul difrerences and being guidcd by then. We must, thus, tum to one of his contomporaries, Prof. Joln Gusian. Prof. Gusian Visited Postalozzi's school in Swituerland and camo alay with thoso impressions: "ro teach a school In the way practicod hore, withont 
bools and alnost ontirely by vorbal instruction is extromoly labortous. The toachor must bo constantly with the child, alvays talking, quostionjng, oxplaining, and ropating. The pupils, howover, by this process are brought into vory closo intinecy with the instructor. Thoir capocitios, all their fuoultios and proponsitios bocomo loid open to his observation. rinis gives him an advanto.je wich connot posgibly be gainod in the ordinary way in which schools aro gonorelly taught. "pho succoss of this modo of ingtruction groctly dopends upon the porsonal qualificetions of thoso who undertako to conauct it. Thoro is no mochaniam in it, no leying dow of prociso rulos fro manazing classos, otc. It is all mind and feoling. Its arrancoments must alveys dopond on the sges, talonts, and tempors of the scholars and require on the pert of the teachers the most alifent and ceroful attontion."

This is obviously not the proceduro followed in our public schoolø. Hovevor, progrossivo oducators wowld agroe with all of it with ono oxception. They would not liko the apporont lack of books. The progressive school movement involvos books and lots of them. But they mould epprove of the closo contrct of the toachor and pupil and above e.11, tho nocossity in Postalozai's systorn of toaching in accordance with tho "ages, telonte and tomporg" of scholers. In othor words thoy would approve of the nocos ity of studying individual difforoncos among tho mupils.

Rogarding tho toachor's pleco in the schoolroom, pestelozzi 
is very much in agroomont with Dovay.

"Tho oducation of man is a puroly norel rocult. It is not the educetor who puts now povers and fecritios into man, and imperta to him brooth and lifo. He only tokes caro thet no untovard influence shall disturb nature's march of developmont. The moral, intellecturl and practical powors of nan muct bo continuod. within himsolf and not from artificial substitutos." (15)

In surn wo find that Rabolais, Lontaigno, Rousceeu, Pestalozai agroo with progrosive oducotors that oducction, to bo successful, mut concern itsolf with thoso two gonoral principle:

1. Study tho individuol child to find his "ase, talonts, and temper" so thot he may bo devoloped to the utmost.

2. The toacher's position in the school mut be one of being a gulde and inspiration so thit the child, with apparont froadon, Will bo stimmatod into aoveloping to his fullost cepecity.

The Dovelopment of the Prosrossive School liovoment in America and the concertod. world-vide movoment.

The devolopment of tho prosrossivo school movoment in America covers a sinort tine ox very rapid groutil. We noed to go back only to the close of the last century to find its bezinnings here.

Join Devey is generally crodito with having started the projressivo school movenent in this country. 


\section{4}

Aloxander lioiklojohn pays tribute to Dewoy in tho 1927 Spring igsuo of "Progrossive aducstion" (16) when he says:

"To that novoment (progressivo educetion) in this country, Ir. Dowoy jave an inftiol impluso; in all its dovolopment ho has boon a dirocting and inspiring force."

Also Dr. Claude 1i. Fuess, toccher of Lnglish at thilips Acedany, Andovor, has this to say in his erticle "The Fromise of Progressive Maucation" in the 1933 April "Curront History."

"The Progroselvo eiucation movenont in operetion is not 01d. Join Dewey's "Iry Podocosical Crood" vas first publichod in $189 \%$.....(and is) accoptod by his followors as tho autrontic gospol."

Harold Ruge of Columbia gives a briof account of tho development of the progroseive school movenent in this country in his book, "iho child Contred school." Ho tolls us that in 1896 John Dowey und his wifo started a laboratory school at the Univorsity of Chicago. This school, founded by the Dovoys, was thoroujiy redicel, having neither school subjects, nor conventionel furniture. "Wany thou ht that their experimontation exemplfiod only scholastic chaos. For sovorel yours it grow $\$$ lovly, e truo imovation, throving overboard moat or the ostablichod principles of order. Losains 'oducators of the country visiting it went away determined not to practico that form of oducationel ane rehy in thoir orm institutions."

Whis school soon becane officially connected with the 
dopartment of education at the University of Chicago but early in the prosont contury Dowoy give up active porticipetion in the school to becomo ar vocal ezponont for the novemont at Columbia.

About thic timo profossor J. I. Horricm establishod e laboratory school o.t tho Unfrorsity of llssourd and oxper1mented for twenty years with a radical curriculum. He began, I1ke Dowoy, with the assumption that eavection vis to draw out the possibilitios in tho child. He triod, st ifrst, to run his school without corpartmonts, subjocts, or schoalules but ho gradualy sev tho impracticability of this and aividod his school into vory general compartments of study, play, rest, otc. (17)

From these ourly boginings tho progressivo school movomont bocomo country-vido. Progrossiro school, privato in naturo, and varying in organiation from radicel to consorvative, that is, vitiout any semblanco of oraer, or with mell dofind curriculum and closo supervision, sprang up c.ll ovor tho country. Important mon in tho oducetional p1old became interosted and wroto books and articlos about tho "now" aducation. Prosidont Cherles Elliot of Hervard wroto, in 1916. "Changos Noodod In Amorican Socondery Education." In tho sumo your Alorahan Flosmor's "Modorn School" apposrod. This offort on the part of Flornor resultod in the ostalishmont of the Inincoln School in Ifey Yorl: in $191 \%$

Othor notable men, such as Bortrend Ruscoll, Evorett 
Doan Ilartin and Willian Iilpatrick took up the cudgol and helped materially in advaneing the movomont.

In his book "Better schoolg" which ho virote in conjunction with Ifyron Stearns, Carleton Vashburno pays tributo to Prederic Burls as the "fathor of individval instruction."

"Trederic Burk, for many yoars president of the San Francisco State Iormal School, can justly be cellod the fether of individual instruction For Jears his voice vas raisod ageinst the cmelty, vaste, and injustice of ettempting to teach all childron the samo things at tho same rete of speod. 'Iocistep' oducation, he called it. As early as 1913, he issued fiory monographs on the subjoct, thet were videly toed and discussed." (18) Hovever, Washburne means apparenty that Burk was the fathor of individus inetruction in this country for, before Burk, there is one to whom credit must be given for formulating tho idea of individual instruction and putting it into activo practice. That person is licdem Maria liontogsori.

Illam Lontossori's cariy training was in tho biological scioncos and it was while she vas sorving as an assistent doctor at the psyciriatio elinic of the University of Rome, just before the close of the lest century, thet she bogan to formulate her podagogy.

Thilo observing idiotic children st tho elinic she becane vory much interosted in the attempts boing made to holp then to dovelop their faculties. Aftor somo exporimontation, 
She conoluded that the problem wa mainly pedagogical, not nedical. In other nords thoir senses had to be trained ana tis of necessity would have to be largely by means of teaching. and not through the modium of modicel science. Of course she did not intend to throw aside her nodical training. As a matter of fect, biology, physiology, and hygiene are vital parte of her pedagory and the scientific nethod is used by her extusiroly as we shal see liter in this paper.

She embodied this idea in a speech deliverod by her before the Podagogicol Congress at Turin in 1898 and stirroi up so much interest thet her vork thoreafter took on a pablic character. At first her work wes with idiotic and backward children but she Iolt thct tho nothods used with deficient chilaron involved educstional principles of moro value to nomel children than those thon in use. She travolled extensivoly during this ecrly period and, after obscrving the ejucctional methous of Irance, Gormeny, and Inglend, becone convinced that normal children would benofit if tho educotional principlos used by her with mental defectives voro introduced into their oucetional systone. She finally had her opporturity to put her idea to a practicel test. (19)

"I had lons vished to exporinent with the mothods for deficionts in a firet elementary cless of normal chilaren, but I had never thought of naking uso of the homes or institutions whoro very young chilaron wore carod for. It wes pure chence thit brought this now idee to my mind." (20) 
She soos on to say that in 1906 sho was invited by Edocrdo Galamo, the Director Goneral of the "Roman Association of Good Builaing", to undertake the organization of infent schools in its model tenements. The idea wa thet each tenoment was to have itg om infent school to bo locetod in the tenement. In these Chilarion's Homes, as they vere callea leter, she hod the opportunity to experimont and formulate her mothods of oducation.

Dr. Lontescori has made hor method felt throughout tho world. Beginning, as she aid, with norsal childron of preschool ago, sho hag dovoloped her podagogy to includo all grades through tho socondory school.

In this country Burls end Washburne have been most active in following hor doctsine and putting it into practico.

Holon Perkiur.t and The Dalton Plon aro porticulerly intoresting becanse Misg Parishust studied with Dr. Iontessori in Italy, later taking charge of her work in this country ana then turning her attention to the school as a human society, that is, as De:oy pictures it. The Dalton Plan, coming still lator, enbracos the two philosophies within tho ono movoment of Prouressivo Education.

In 1904 Iifs Parl hur.t took hor first teaching assignmont in a rurel school. Thoro woro eight grades and she was the only teacher. Thus she had the problom of giving oral instructions to ono class and at the same time reep seven othor clossos bysy. To do this sho tried the project method. She 
transformed a storeroom into a library. In this library she tarked off sections for each subject and tien, by getting tho older pupils to help the younger ones, she set up a system whereby the children chose a projoct and then vere alloved to movo to and fro from tho library to the classrom and back to tho library as they sav fit. The idos norked nnas she moved Irom one teaching position to anothor the jdea stuck in her mind. It eventualyy resulted in the Dalton NIen.

In 1908 she ran across Hagar James Suft's "Mind is the liaing" and it inpressed hor beceuse it nut into vords the thing that she had beon mulling over in hor mind. In her book "iho Dalton Iaboratory Pqan" she quotes a passege Irom Swift which she considers pertinont:

"rihe rational mothod is to Work vith the students, inepiring them with lowing to dolve into things for themselros, and to malre thoir contribution to the comnon fund of knowledso to be diacussed or clissifiod in the recitetion. The didactic methud belonge to tho waulo sove. It still dominates our schools, though the conditions the mede it serviceable have long since passed. Liental expansion of the tocchers thomsclves is the first stop towerds removing this nedieval dobris. They will thou invostigeto tiroir pupils, the schoolroom vill become an educational laborctory, and ectivity vill not be linited to the manuel training department. The influence of sucgestion throuth environnent has nover receivod its propor rocogrition in education. Teachors lent to play a too con- 
spicuous nart in the oducation of tho pupils. But the oducator is limited, in the ends he may preelect by the comple:ity of human life. The very child those qualities he disaproves of any be the jom of $\varepsilon$ man much beyond his oun mental reach."

Ihis book gavo her the firm resolution to becone a free lance in education and exporinont.

Threo years later she began arafting a plan of work. She had It woll in hand in 1913 but it wesn't until 1915 that sho succoeded in oliminating the "time tablo," as she calls 1 . The idod in her plan was to jive children more freodom and rovide enviroment better adepted to differcnt sections of their studies in wich ooch inetructor vas a specialist.

In 1914 she iont to Italy to study with Dr. Lontessori and the noxt year sho returned to this country to particiyete in the application of tho liontessori metiod in California ind act in the offlcial capacity of assistant to Dr. Lontessori. It wes here, throu. h the courtesy of lir. Burk, that she riu de a practical application of the laborctory plan unon a solected group of 100 children botween 9 and 12 years of age.

Botwoen Decomber 1915 and Janury 1918 she took chergo of Dr. Montessor1's interests in America. At the end of that time she folt that she had dovotod suficient study to the individual aspect of educntion and rocedoa to teke en interest in the school as a human socioty.

In Soptomber 1919 her "Plon" was applied to an ungraded school for crippled childron. It workod out very success- 
fully and the noxt yoar, 1920, it vas applied to the Dalton, Hassachusetts Iligh School and sained mch attention hore and abroad. (2I)

The Plan apparentIy did not meot with success at Dalton, howovor, becauso it gradually disappeared until in 1932 it vas completely oblitorated.

It is evident thet the progressive gchool movenant is indebted to Joln Devey and Heria Iontossori for clearly establishing tho principles underljing the movement snd deroting their interests to the developrent of those principles. Rebelais, Roussery, and lonteisno, although they sav some of the shortcominse in the treditionel school, nede no attempt to round out a full boay of aducetional mineiples wich would tale the place of those in uce in their eay. Pestalozui put the princintes of hic oducetion into active prectice, but becuse it wa:n"t the "peychologionl moment" perhaps or because of his inabilis to reach the world at largo, minly because of his vague and unintoresting stylo of witing, he did not surround incelf with supporters. Irot so in the caso of John Devey and Ifarie Inontessorl. Whese tro people heve had the feculty to Eet othor pooplo intorested in their principlos of Education. Devey, at Columbia, has surrounded himelis with ablo men, such as Harold Rugo and "illian I"ilpatrick, mon who have tho feculty of viting in on onsy and intoresting style. Dowey himcelf Lcs written a large amount of moteriol, cni vililo be is very vague at timos, he has succodcd in firing the incinetion of a 
number of poople who have put his philosophy into practice. Somo of theso nractical attempte have followod Dewoy too literally porhaps, and the result has not mot with genoral approval. others have tompered his philosphy gonewhat with fects gainod by experience, and the results soan to be moro rational.

Ifaria liontessorl, in Italy, has gained torldwide recosnition es one of the foremost oducutors of the dey. Being a pioneer and radical, like Dewey, in the light of past methods and thought re_araing education, she has been exposed to a great deal of criticism, sonetires flagrant riaicule. Sho has carried on, nevertieless, and now is woll esteblishod in itely and is oining footholds in other countrios.

The development of the nrogressive school movement is, thon, tho story of dorinent personalitios who sew thoir ideal snd have sought to roach it. Any discussion of progrossive oucation in the Unitod states, accordingly, nust ve in terms of what those dominant personalitios such es Helon Farlthurst and Carleton Tashurno havo done in intorpreting those principles. The few reforences mede to isoleted attompts in following the principles of wither Deroy or llontoesori or both, will undoubtody bo colored by the miter's point of view first, bocause of a. lack of vitten material of an informative or critical noture; second, because of the difficulty in Keoping ono's porsonality out of a guject so controvorsal.

Boforo going into a discussion of principles, homever, en indication of the scope of the vorld-vide concertod movement of 
progressive education is essenticl.

In 1919, a snall group of teachors and others interosted in progressivo education organized to form the Progressive Education Association which, at the precont time, numbors alnost seven thousand members. (23) In 1924, The Ascociation began publishing tho Progressive Educetion magazine, the officiel organ of the Progressivo school movoment.

The Association is affiliated now vith tho Hov Education Fellovahip, a vorla vide organization of persons interestod in the progrossive school movoment. Othor countries, connected with the Followship, with progrossive school sssociations strong enough to support a megarine are: England, Frence, Gormany, Argentine, Belsiun, Rulgana, Czecho-Slovahia, Domari, Hungary, Italy, Japan, Jugo-Slavia, Paraquay, Portujal, Runania, Spain, Swocion, Turkey, cnd Uruguay. Countries affiliated with the Followship, which have en octive group inter cted in spreading the princinles of progressive oducation but tho do not publish a negazine, include practicelly every country on the slobo.

Tho Now Eaucation Fellowship was founded in 1915, in England, by Boctrico Lnsor end a group of her frionds vnder the nase of "Praternity in Eucstion". "From the first it was an international movoment designod to gether together in fellowshin those who belioved thet the problems throatenine our civilization wero besically problens of human rolationsinip thut have their source in the fndividual, and that because the 
Indiviaur was tho pirst concern of education, it wes tho suprome task of the homes and schools to provido non End vomen responsive to the now demands of a changing world."

The first three conforences of the Fratcrnity wore held in confunction with the Hew Idosls in Educetion, an Englich Pionoer educational association. By 1921 the Eretcrnity had roally become international in scopo and that yoar the firet international congross wes hold at Calais. At this conferenco it wes docided to reorganize the Freternity on a vider besis and the namo IJow Lducational Follonship was edopted. Sinco then there havo beon five internationsl congresses held, at Jiontreux in 1923, Heicloburg in 1925, Iocaxno in 1927, Elsmire in 1929, and Irice in 1932. Thoso congrossos have boen hold to discuss educational probloms and to oxchange constructivo educational ideas among tho delegates fror all ovor the world. (24) 


\section{PRIICIPETS OF PROGRISSIVE EDUCATIOI.}

The two broad divisions or Progressive Education.

Reference has beon made to tho fect that Helon. Parkhurst, crootor of the DaIton Jaboratory Plan, folt in Janu ry 1918 , that she had devotod enough study to the individualizod oducation of Dr. Irontessori and thercafter took up an interst in the school as 2 human socioty or Dr. Dewey's socialized eâucation. The infercnce is that $\mathrm{Dr}$. Ilontessori and Dr. Doroy, both very important porsonages within the gonoral fiold of nrogressive education, diffor in their viows reguraing the philogophical basis and gonoral method of procecure in thoir respective theorics of eucation.

Anna Tolman Smith, in a review of liontossori's "Tho llontessori llothod," makes a brief refcrence to their aifforing viev points.

"Whe doctrine of liberty is not new to the educetional world of the United Statos; It mas not only formleted by Dr. Dowoy, but wa precticelly exuplified in the Unircreity Elomontary School, at Chicago. The llontossori llethod, howover is based unou social relations as those oxist for the child elther in acturil exporiences or living intersts. The differonce is great and is readily explained by the fect thet the formor orrporiment began with defectivo chilaren; thet is, with chilaren wixoso infirmitios proventod their roudy aductmont to normal society, oven in tho elonentery form of homo lifo." (25)

Tho differenco botwoon liontossori and Dewoy is funda- 
Lentally the differenco botweon tho scientist and tho philosoinor, tho oxporinontaliet and the ompiriciet.

Ills Smith aays revarding Dr. Lontessori:

"Ivery now syctom boers tho gtamp of a personality....

In the case of Dr. Ilontessori this onergy has boon directed by prolongod training in tho sciences thit roluto to human lifo and vitalizod by practical oxporionco in their epplication to noody and dofectivo cirizron." (26)

Ifontessori is a sciontist. Her treining hes boen in anthropology, biology, physiology, and hygiono. Hor gyschology is tho mathomatical and oxporimental psychology of Webor, Fochner and Wundt. Her miny roforences to anthrometry and. psychomotry infor that she looks on all science as susceptible to matheraticel proof. Sho sejs in "Tho Montossori liothod:" "Yhysiological or oxporimaital psychology which, from Wobor and Fochnor to Wunat, has becomo orgenizod into a now scienco, seems destincd to Iurnish to the new podagosy thet fundonental preparation which the old-ti a notephysicel n=Jcholagy innished to philosophioal podagogy." (27)

Sho saye lator in the samo chapter:

"For sevorel yoal's I havo dono battlo for in idea concorning the inetruction and oducation of man which apposrod the more just and usoful tho nore dooply I thou ht upon it. My 1doe was that in ordor to osteblish netural rations methods, it was escential that wo nelo numorous, o:act, and rational obsorvations of man as on individual, principally during in- 
fancy, which is the ago at which the founations of education and culture rnuet bo Iaid.

"To measure the head, the hoi ht otc. does not indoed moan that wo are ostaibiching a systom of podagogy, but it indicatos the road which we mey follow to arrive at such a. syctem, sinco if wo gre to odrcate on inalvidual, wo must havo a dofinite and diroct browledo of him." (28)

The important thin to bear in mind about liontescori is that her first experience in ocucation wes with montal defoctives. Individual aifforonces anong theso unfortunates variod to such a dogroo thet a highly individualizod mothod of education was necescary. In adition, as is so ofton true among pooplo of vory low intellisence, their hodies vere deformed and glands and other organs did not function nomaly. As this physical condition had a direct boarine on thoir montul processes, it was nocescary to make very detailod and comploto examinations of each individual at intorvals. This is the beckground of educotional training that Dr. Montossori carriod ovor to normal childron. As pointed out proviously sho was so succossful with mental defectives thet, when sho hod the opportunity to oducoto nomal childron, cho carried ovor, bodily, tho mothods ond tochniques wich she had used with the dofectives and anplied them to nomol childron.

Dowoy, on the othor hena, E philosopher and sociolocist. Ho thinis in torms of groups. Ho rocognizes the principlos of individual differonces, of courso, but only in the senso that it 
allows ach mombor to contributo to the srowth of tho group. "A gocioty besod on custom vill utilizo individuel variations only up to a limit of conformity with usago; uniformity is the chiof idoel within oach cless. A prosrosaive socioty counts individur variations os procious sinco it finds in tinom the means of its now growth. Henco a comocratic socioty must.... o.low for intelloctur froodon and tho pley of divorso sifts ond intorests in its educ tional moscuros." (29) His is the ossontial difforonce betroon tho two. "ihile liontossori meleos individual difforences paramount, Doiey subordincties but usos thom for tho erowth cnd onricimont of socioty of which unifomity is tho chiof idoal. It is quito eviciont, thon, that sinco linoy ero sonerelly concidorod tho lociling oxpononts of prosressivo education, tho progressivo school movonont consists of two broad divisions, the thoroughIJ individualizoo aducation ol Dr. Hontossori and the sociclizod oducetion of Dr, Dowoy.

Principlos undorlying lontessori's thoory of oduction. In tho oponing chaptoz" of "The hontossori lothod", IIontossori malos roforence to and attacks provious attompts et

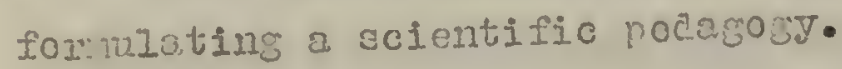

"In Mranco, in Hinglend cnd osnocially in Amorica, orrvuiments hove boen made in the elementary schools, bssod vnon a study of anthronolosy snd psychologioel podegosy, in the hopo of rindins in anthropomotry and psychometry, the roconeration of tho school. In tioso attempts it hes raroly boon tho 
toachors who havo carried on tho rosecrch; the experinonts have boon, in nost cosos, in the hands of physicians who havo takon moro intorest in thoir ospocial scionce thon in oducation..... so sum up tho situation brie11, anthropology and psychology have never dovotod thomelves to tho quostion of caucating children In the schools, nor have the scientificsily trained toachers evor moasured up to the stendards of gonuino sciontists.

"Whe truth is that tho practical progross of tho school aomands a gonuino ingion of these nodern tendoncios, in practice and in thought: such a fusion as sholl bring sciontisto dirocty into the important fiold of the school and at tino sane tino raise toachers from tho inferior intolleoturl level to wich thoy aro limited today." (50)

Hor ploe is for the advanconent of tho school and toacher by brinjing sciontific frowledgo and mothod to applo directy to the intorests and progress of edveation. The toachor must bo e scientist, grounded in the nrincinios of enthromotry end psychomotry.

"Io propere teachors in the mothod of tire oxpoxinental scionces is not an easy mettor. When wo shell havo instructed thor in antinomotry and psychometry in the most minute manner possible, wo sirul heve only croated machines whose usefulnoss wiIl be most doubtful." (5I)

Thon she goos on to attack the toachor and teaching methods in tho "ola school" as Raivelais, Montaigno, Postalozzi, 
Dowoy and countleas othors havo done.

"The toachers of tho old school, propared according to the prinoiplos of motaphysical philosophy, understood tho ideas of cortain mon rogardod as 2uthoritios, and movod tho muscles of spoech in talking to them, and tho muscles of tho oyos in reading thoir thoorios. Our sclontipic teachors instoed, aro faniliar with cortain instrumonts and lnow how to move the musclos of tho hand and arm in ordor to use these instrumonts: bosidos thig, thoy havo an intelloctual proprration which consists of a sories of typical tosts, which thoy hovo, in a barron and mochanicsl way, loornod how to appIy.

- "Mho differonco is not substantial for profouna alfferencer cannot exict in extorior teaching alone, but 110 rathor within the fminor man." (32)

In bxinjing in the mystical concopt of the "inner man," Irontossori exposes herself to the att ck which has boen ncdo against progressivo oducation in goneral. Prof. Fandel of Columbia sums up this chareo in the Februery 1933 issuo of the Ioschers Collogo Rocord:

"(Progressivo oducators) have concistentiy rofused to bofino goals or ends in advence and havo roliod on tho masic of grovth, self-exprogsion and dovelopmont from within."

Dr. Nontessori oxplains th the thing that must come from the innor solf of tho teachor is tho spirit of the roal scientiet. 
"Who sclentist is not the clever menipulator of instrumonts, ho is the worshippor of nature and ho bears the oxtornal symbola of his passion as does tho follower of somo roligious ordor. In this body of roal scientiste bolone thoso who, forgotting, I1re the Prappiste of tho lifalie Agos, tho world about them, Iive only in tho laborotory, aaroloss ofton in the mattors of food and dress becsuse they no longor thing of thomsolves; those who, throuch yosrs of unos riod use of the microscopo bocomo blind; thoso who in their scientiflc ardour inoculato thomselvos wth tuberculosis germ; those rio hanalo tho excremont of cholore pationts in thoir eagernoss to lourn the vohiclo through whioh descasos ero trensmitted; and tirose vho, knowing that a cortcin chomical preperotion may bo an explosive, still persist in testine their thoories at the risk of thoir livos. This is tho spirit of the mon of scionco

"whoro orists, thon, the spirit oi the sciontist, a thing Iax above his noro mochanicel skill and tho sciontist is at the heicht of his achiovoment when the epirit has triumphod over the mechenism."

Wo vill agroe thet oven a smo.Il part of this "spirit" ingtillod in sIl ous toachors woula bo sn incaeaveblo bloseing to education. Wo will agroe that those porsons who possoge thut spirit whothor they bo teachors, aoctors, Iavjers or what not aro capablo of and ueuliy aro of decided voluo to mankind. Doubtiogs many persons hovo ponderod over tho 
problom of how to ingtill more of this gpirit into more of our toachers. Ho ono, hovevor, hes discovered the formuls. Iontossori passos it by a.s not worthy of diecusgion.

"But lot us put agido tho aifficulty of proparing sciontific mastors in tho accopted senso of the word. We will not oren attompt to outline a progren of auch proparation, since this would 1 cad us into a discussion which hos no placo hore." (35)

In the discussion of any oducotional method so dopendont on the curoful training of tho toacher it does not soem roasonale thet a aiscussion of hov the toacher is to be tralnodis out of placo. liontossori is apparently recorting to the ase old practice of dodging the issue.

Fron that point liontegsord goos into a discussion of Iiberty and freedor.

"It is not onourh.....to proparo in our lirstors tho sciontific apirit. Wo must also mako rody the gchool for their observation. Tho school mut pormit the freo, natural minfestations of the child is in the school scientific podagocy is to bo born. This is the escenticl roform.... (54)

moday wo hold the pupils in school, roctricted by theso instrumonte so dograding to body and spirit, the desk--and metorial prizes and punishment. Our eim in all this is to roduco thom to the discipline of invobility and relievo,---to load themp---where? Far too oftion towerd no dofinite ond. "th, before such denco end villful aisregard of tho iffo 
which is groving within those children, wo should hide our howds in shame and covor our guilty facos with our hande!" Montessori choosos the dest in the traditional school as the nodius through wich she attack the lock of froodon for tho childron. Sho dislikos the dosk in the traditional school for two rossons:

1. Tho dosk is an ozamplo of acientifio knovledgo appliod too litorally.

2. It is a hinarence to senitation.

"....Thon camo soionco and perfectod tho bonch. In this wory much attontion we paid to tho recent contributions of anthropology. The ajo of the child and the length of the limbs varo considored in placing the soat at tho right hoight. Tho distance botwoen the seat and the dosls var calculated with infinite care, in ordor thet tio child's bock should not bocome doformod, and finaliy the socti wore scparated and the with so closoly calculated that the child could barely soat himsolf mon it, while to strotch inselis by makeing latorel movomonts wos impossiblo..... Those deske vise construeted in such a vay as to rendor tho chila visiblo in cll his immobility.

"It is all so arrongod that, whon tho child is vollfittod into his place, tho dosis and cheir themsolvos lorco him to assume tho position considorod to be hygionically confortablo. Tho soot, tho foot rest, tho alosk kro arrenged in such a way that the child can novor gtend at his work. Ho is 
allottod only sufriciont spaco for sitting in an oroct position. It is in such vays that schoolroom dosks and bonchos have advanced towerd porfoction." (55)

It Is apparont that liontossori resorts to oxaggoration to bring out hor noint. The dogks and chairs in our traditional schools are not tho straight fackots sho picturos thom to be, of course. Her point is woll takon hovevor.

Host of us cen visualizo the appearanco and atmosphoro of the public school clesgroon. Iet us, tion, get a picturo of the apposance and atmosphere in e progrossive school. (30)

On ontering a clags of eighth graders in sociel scionco at Gill Hall in Northempton wo aro innociately impressod and ploasnty so by the informal, honelike appoaranco of tho room.

Tho room is about the sizo of a good sizo living room in tho averaje homo. The valls are palnted brown up to a littlo beyond the roach of tho children and a lisht jollow from that point to tho coiling which is at tho ordinery hoight of the coiling in tho home.

Thore aro two large vindows on ono side of the room, curtained and arapod with an inoxponsivo matorial which adds immocsurebly to tho homoliko atmosphore of the roor. Flov plaiu and drab tho windows in tho public schools appory by comparison:

Tho doskr are sinilar to tho dosks in our public schools, 
oponing at the top by raising a sloping lid. They are not fastenod to tho floor and so may bo arily moved about. Tho chairs are tho ordinary gtraight back typo with ruch seatg and thoy, Iike the dosks, are paintod a pale blue onamol. The dosks and chairs are very sinplo in dosign and so aro oasily cloaned. Thore aro fourteon boys and girls socted at thoir desks which are arrangod in a somowhat seni-circular feshion. Io attomnt is made at perfoct symmotry but tho appoarance is ono of ordorlinoss and is ploading.

Thore is a blackboard on tho wall at the front of the room and off at the roght but in front of the class is tho teacher's desk. It ie the ordinery double podestal effair. The raised platrorm on which the toachor's desk is somotines enthronod in the public schools is miseing hore.

The difference is ono of aim. The designors of our public schools have beon primarily concernod with giving tho childron plenty of light and Iresh air in tho classroon. In adation thoy have tried to save tho taxpayors' money by colculating tho numbor of squaro inches tho child roquiros to movo in and tho numbor of squaro foot of air oach child re(1uires to breathe. They have then arranged the number of dosks and chairs in the classroom accordingly. Abovo all, as Dr. Nontessord points out, they have follen in line with tho falso idoe that tho bost wey to havo ordor in tho classroom is to construct and arrango tho desks and chairs in such a mannor that order must automatically follow. rihoy lose sicht 
of the fact that human naturo nover rosponds favorably to un imposod condition thich doos not heve the eympathy and cooperction of public opinion. Witnese the olghtconth amondmont. The win of the prosrossivo school is, it soons, nore retionsl in this regard. Whout losing sight of hyglenic princinlos, uil attompt has beon made to create a plossant hamo-1itro atmosphero in the claseroom. Of courso the underlying principle is that human boing respond moro fuvorebly to stimuli if they aro contontod and happy. Iifo insuranco salesnan inform us that tho bost tino to approach a man is aftor ho has ind a good dinner and is smoling a good ciger. The socond issuo thut liontossori reisog rosardin; the dosk and chair concorns senitation.

"Wven wore the stationary coat helpful to the child'g body, it would still bo a dengerous end unhysionic focturo of the environment, through the difliculty of clenning the room porfoctly when the fumiture cannot bo moved-.-- ioday there is a general transfomation in the mattor of houso furnisinings. They aro mado Iightor and simplor so thet thoy may bo oasily movod, dusted and oven washed. But tiro school seoms blind to tho transformation of the social onvironnent." (37)

Iontessori is obviously corroct horo. While sho is porhaps too apprchongivo of the dangor of gorms in tho dirt affecting the childron, tho fact raming thet dirt collocting on tho floor around tho logs of the dosks and chairs ie 
not conducivo to promoting cleanlinoss end neatnoss in tho childron and doos not add to their rell-boing.

Montossori'g idoe of olagsroom furniture $1 \mathrm{~s}$ interesting and unfuro. In coneldoring this subjoot wo must boa. in raind that the childron in the "Childrons Houses" range from three to gis yoarg of o,ge.

who principle modification in tho mattor of school furnishing is tho abolition 0 i desire and bonchos and stationary ohairs. I havo had deakr made with mine, suiid, octo.gonal logs, sproading in such a vay that tho tablos aro st tho samo timo sol1dIy firm and vory light, so light indood thot two 4 yoar old chllaron can oasily cerry thom about, The tablos are roctangriar and suficiontiy largo to accomodato two chlidron on the lone a1do...."

"I 2.1 so designod and had manufecturos littlo chairs. In adation to theso, I havo in esch schoolroom a numbor of comfortable Iittlo am chairs...."

"Anothor plece of our school furniture consists of a Iittlo vish stend..... The tops or .....ceses fumish room for pottod plants, small aquariums or for tho various toye vith which tho children are allowed to plo.y frooly. Wo hevo cmplo b1acrboarå spaco.

"Abova the blockboards aro hung attractivo pictures... (58) The important thins to consider in this doscription is the attractive hono atmosphore crected. It is one of tho chief contributions of tho progrossivo school movonont to ed- 
uoation.

In connection wh th the classroon she provided for an amplo playground uth space for $\varepsilon$ garcon. "Tho idoa lios perhaps, in my idea for the uso of this opon ali apaco, which ia to bo in aireot communication with tho schoolroom, so that tho chilaron may bo Ireo to go and como as they 11xe, throuchout tho entiro aลy." (39)

This froadon of tho chjldron is encoureged so thet a mothod of obsorvation nay bo formulated "upon one fundamentel woso--tho liborty of tho pupilg in thoir spontanoous manifostations." (39)

In other words sho advences tho principlo thet in ordor to - vauto the child ono must havo a dotailod mnowlodge of him. To repeat: ".....I have a dofinito and direct mowlodjo of him."

Sho appreciates the angor of this proceduro then she sayo thet herotoloro sciontists have mado observation of school chilaron, not in tho intorests of oducation, but of their ospeciol sciencos. It ja apparont that with the roquiroment of such 8 detailod obscrvation of children vill do tho dangor of tho chilaren tring on the rolo of guinoa pigs in a laboratory. The raal objoct of the obsorvation is 1iablo to bo loot gight of.

Montossort doplores the genoxal uso of prizos snd punishmonts in tho public schools to promoto incentive for vord. "But to who would accomplish a tiuly human work, ho who 
doos sorething roelly groet and victorlous is nover spurred to his task by those triflins attrections, callod by the name of "prizos" nor by the feur of those potty ills which wo cell "punishments." ....( $₫ 0)$

"All human Victorios, all humen prosross stend upon tho inner 10ree." (LI)

In conclusion, it is ovidont that the principle of individuelized instruction, involves tho principle thet tho inaiviaul nuct progress at his own rato of spood.

This principlo is the fundemontel bssis of individunized instruction. If it wore otherviso it nould of necescity be collectivo instruction wich has its basis on the principle that tho rate of the group governe tho rate of the indiviual.

In suming up Dr. liontessori's phizosophy of cducation wo find that it involvos tho following principlos:

1. Inaividurizod toaching.

2. A sciontific und spirituel bu okground for the teacher.

3. Froodon of tho childron, which involvos revolutionizing tho etruosphore of tho classroom into ono moro adeptablo to freo movemont and moro cheorful and home1ilvo, for tho purposo of scientific obsorvation by the toacher.

4. Abolition of prizes and punishinonts wich involves tho abolition of the marking system.

5. Progress of tho chila et his own rato of spood. Prinoiplos undorlying Dowey's theory of eaveation. 
Dowoy, 2s we havo pointed out, doos not agreo with tho firct principlo in this summary.

In reicra to the toachex, Dowey egreos wh thontessori that tho teachor's prine function in tho school is thet of an obsorvor. His statoment, yuotod proviovsly, thet tho toachor is not in the gchool to imposo certain idoas or form definite havits in tho child makos his attitude cloor and dolinito on this point.

Howovor, he differs with llontessorl regerding tho onds he 1tshes to accomplish. In"Domocracy and Education" he csys that "the noturel and nutivo implusos of the youns do not expo with tho life eustoms of tho group into wich thoy aro born. consoumentiy, they have to bo dirocted ind wided. This control is not tho some tining as nhysical complusion; it consists in contoring the implucos actinc t ono tirno upon somo speciflc ond and in introducing on order of continutity into the coquence of acte."

While llontossori's mothod oncourgges spontanoous activity on the part of tho children for tho selro of mothodical scientific observations; Dovey insists thit spontencous activity In the nutivo and naturel impluses of tho youns do not agreo with the Iifo cuctome of tho eroup and must bo guided. The teechor, then ousorves tho child only thet sho may cuido him olong tho road of correct group bohavior. Tho aifforonco in thoir points is indicativo of thoir fundemontal difforences. "Undorlying Dovoy's omosition (oI obsorvation or convar- 
soly) of learning by doing thero is an aseumption that noeds oramination. It is this: givon an adequato mediun, the individual ohild by cooporting with otherg vill roact in such a. way thet \& body of information, habite, attitudo snd 1docls will evontunte. Without the intervention of a cupcblo toachor, tho possoses oxplicitiy and porfectly wht ho visher tho pupils to possess in turn, it is eesy to soe the such a rosult will not ensue."

"Iosinning by doing expresses the exporimontal approach to subjoct natter......ivery ono recognizes the tremendous influonce it has on tho school. It is oscenticl to real leernins.... Howavor, to considor it tho only mothod to be made uso of would bo to instruct tho teachor end--nerrov down the possibilitios of loaralng with the child. Thore is also tho telling nothod. Tho teacher makes use op it in supplying ideas to the punils.... It onds in the overcomin of alfficulties and in grating the pupil's mind to seo tho rolition wotwoon thing, and to come to sound conclusions. Nith Dorey, subjoct-matter is ovor in the procoss of moking and this accounts for his omphasis in loarning by coing. As far as tho child is concornod, subjoct-mattor is continvally boing mado in the souso that the child is over coming into the poseasion of the olomonts of Iffo. Howovor by rosson of its origin. some subject-motter hos boen made; by reason of 1 ts nature, somo subjoct-nattor is pormenont. Universally accopted olononts in the social horitage and firmly ostablichod truths 
indicutes the pro-existunce of somo subfoct-matter. The ocquisition of cuch veluos mike the major scopo of the work of the pupil and toachor. Iho guidins rolo of tho teachor in locding the chila mine to the rocognition of such pormanont olomonts chows tho importanco of tho teachor's work..... Tho toaching mothod supplios meenings and values to tho omperinontal nothod. It does not supplant tho lattor rathod..... Tho two mothods are necossury in the school. Tho "old" oducation put its omphesis on tho teling nothod; the "new" puts 1tg omphasis on the experinental mothod. Devoy doos not rule out ontirely the formor, but ho tonds to minimizo its inportonce." (4.5)

Thus Dr. Ohare suras up the criticism which has boon launchod at the "Ioarning by doing" or observation principlo of llontossori and Dewoy. It is ovident thet thero is a place for both tho exporinontal and tolling mothods. As he points out, somo subjoct-mattor is mado, somo is pormanent and tho acquisition of such univorsally accerted truths and olemonts ombodiod therin marks tho major work of the punil and teacher.

The IIncoln School is run in comnection with Toschors Collego at colurabia and is thorouhly progresgivo in mothod.

In the ronchars Collejo Rocord for Octobor 1928 thore is an articlo entitled "Iincoln school as a Punil Soos it" writton by Pevilne Frances Bacrnald, senior in the school. In this articlo Liss Bwornald gives her reaction to tho method of instruction in that school. 
"There wa a year in wich wo studiod natural resources. Wo wont along step by stop, tople by topic, and thon suddonly got side-trackod. The conditions of tho coci minors intorostod us. Wo sturiod thoso in actial, dospito tho fact thet thit phase of the surfoct had not bool a fouturo in tho outine of tho courso."

Vo mut asgume that it vas not a fosture in tho outlino of the courge bocause the teachor aid not consider the topic worthy of that dictinction. It secms, thon, that tho tescher, althouch having : woll dorinod ordor of continuity in hor study, bocame ontemgled in tho mosh of Dovey'a mrincinle 1.0. "five c child Ireodom to sind out wht he can do.... and ho will not wast much timo on impossibilitios but will bond his onorgies to the possibilitios" and alloved the class to follow thoir oun intorosts. Abendonnont of tho obsorvation mothod and tho application of the toluing nethod might havo boen of value horo in irupatin rokl veluos ena showing materigls in thoir truo proportions.

Thoiro aro two conflicting principlod in Denoy's progrossive education which must be concilietod if it is to so offectivo.

1. The principlo of solf-sctivity, loarning by doing or as Dowoy puts it, "bolding tho onoreics to the possibiIties."

2. The prinoiplo thit the teacher mu.t havo specific onde in viow and a woll dofinod ordor of continulty in approaching thoso onds. 
Doubtiess, in those phases of educetion to which the sciontific metiod coula wo applied advantagoously, thoso two principles, if conciliated, world bo effective. From a Utapian vior point, tho toschor wauld lnow exactly what ho wantod to acoonplish and exrotiy how to do it. Thon by atimvation of aractly the right kind tho children vould roact juct as ho visher thom to and would procood olong the channel prescribod, with intorest, to tho ends sot by tho toacher.

But tho quostion arisos: Is our great body of toachors capablo of conducting this sort of prococuro succescfully? It wovla soom that the successful outcone or such a procedure mould dopond on tho abilitios of a hijhly gifted porgon. Dowoy's concoption of what classroom atmosphore should De is idontical with that of l"ontessori.

"A vistor to the now school cannot but be improssed by the many changeg wich hevo como ovor oducational practico as exhibitod in them.... Tho vistor vould observo that the clessrooms aro noro attrativo, moro lightsome, moro airy. The now school attonpts to prosont tho best conditions of the icioal homo.... Thero is a chango in tho atmosphere of tho school." $(\leq 1)$

Dowoy condemis extranoous motivetion. "Intorost is takon to moan morely the effect of the effoct on an anjoct mon porsonal advantaco or diceavantaso, succose or failuro. Soparatod from any oijoctivo dovelopmont of affairs thoco aro reduced to moro nersonal statos or pleasure or pain. Iaucationily. 1t moans to ettech some focture of soductivenoss to 
material othorvice indifferent; to scoure attontion and offort by offering a bribo of plesure. The procodure is proporly gt1gnatized as "goft" podagosy; as a"soup k1tchon" thoory of oducetion.

I "But the objection is bisod upon the fuct-or assumptionthat the forms of glill to be acquirod and the subjoct-matter to bo appropriatod heve no interost on thoir ovm eccount." (45) Interest must wo cainod by moring the subject-matter intorocting, not by settin up a prize to bo gained by good voris or a ponolty to bo eractod for bad work. Tho prizos end ponaltios must be in torms of spiritual, not meterial values. "Al1. human victories, 211 human progress, stcnd upon the inner force."

Progressive oducators aro agreod throughout tho movement that tho grading systom as an examplo or oxtrenoous potivation must bo abolishod. But thoy aisegreo in thoir reasons for it. Dewoy with his prineiplo of socielized oducation holds tho viow that individuals must contributo to the erowth cnd enrichnent of tho group whoto "ideol is uniformity." Accordingly in a study of the Foudal system in history ono cinila vill bring informetion to tho closs about castles, another about serf and country life, anothor about werfare, anothor about govemnent and so on. (46) Each child makes his contribution to tho group and his reward mat bo the inner fecling that ho has ano somotiing worth while.

Dowey mas no direct statenent resarding the princirle 
of individul progress. Subordinating, 2.8 ho doog, the individual to tho wholo group wo may not as sumo that ho bolloves that the indiridual may prosrogs at his own geit without regard tor tho wholo group.

"Ola fashionod toachors aro thoroughy firchtonod at tho amount of froodom in tho chila-controd schools.....tho reguler sohoolroor toachor does not havo a day chopped up into ragular intorvals. Childron do just what citizons do. If ono is worleting at somotining and tho noon hour comos, he drops his worls goos to lunch and thon returns and finfehes the job.

"..... Supposo tinet childron aro working un the history of book makins. Sone are making illuatrations, some aro cloaning and taning shoopskin, sono aro unrevoling the thread from the silk worm cocoons which thoy have grovn and somo are lettering. somorrow tho puplls vill be doing what senme tho next bost tining to do....

"Porhaps the roador may bo holpod by compering the typickl subjoct-matter of our Americen school with thet of one of tho nov sahools."

1ypical Amerioan Curriculum:

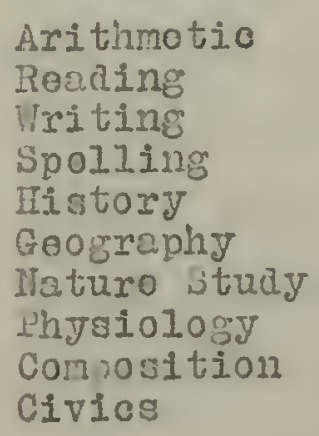


A Child-Controd school Curriculum:

Our community Iifo, omphases on food, harve ting, throshing, milling, olothing, weaving, dyoing, chd and study of Indian 1110.

Scionco and nature study of local onvironment. Greek Ilfo as presentod in the odyssoy.

Gardoning, the Eair, Thankesiting basketo for tho poor.

Georraphy--study of llorth Amorica ce sotting for its history. $(47)$

This cooperative aotivity is consistant with Dr. Dowey's pxinciplo that the school should reprosent lifo in ite ombryonic form, i.a. Iifo consists of a socioty, occh member of which ahould contribute to tho onrichment and Erowth of tho group.

The child-controd school ouriculun is a good oxamplo of what Dowoy Intonds it sinould bo. "rhe subject-mattor of oducation consists primerily of tho meanings which supply contont to oxiating sociul Iife." (48)

It follows, then, that, since Dovey subordinstos the indiviual to the interests of the wholo group, ho boliovos that the individual's paco must wo commonsurate with tho wholo group. There is thia coneideration, however. Tho degreo of mastory of any pioce of rnowledso is up to tho individual child. Thilo Irontossori insists that esch child muster a uivon assignmont "ono hundred porcont," Dovey lodros it to the individual child, with the aid of tho toacher, to get as much as ho can. "Givo a child froodom to find out 
what he can and cannot do... and ho w11l not vaste much time on impossibilitios but will load his enorgios to tho possibilitiog." (49) Ihis principlo has lod many obeorvors to throv riauculo at Dowey. Hicholes liurro.g Butlor, in a lecture at tho convocation of the Univorsity of the stato of Now Iork at Albany, Octobor 17, 1929 ahd this to sey:

mho protty comploto abandoment of tho doctrino of formal discipline has deprivod school teaching of any objoctive that really mattors. Wo aro now actuelzy invited and urgod to tako as our modol for the oducation of tho American child, the cow, which grasing lavily in the pasture munchos what ploasos tho oyo and is likely to fill the stomech.

"Iine rosult is so plain that no ono can bo exoused for foiling to soo it."

Dowey, no doubt, is too optonistic ss to what the individual will do if left to his own interests and his concoption of whet his possivilitios are. Who learning by doing prinoiple in applicution to his assertion that the child if glvon his froodom vill lend his onories to the possibilities moans that tho child by realizing his possibilitiog will imadiately go to work and fulpill then. The underlying prineiple horo noods to be considered. It is this: tho avorase child is so constitutod that he knows his possibilitios in advanco and znowing thom will endoavor to brins them to furizilment. This principlo is too idaliatic for practical application. Wo know of inctancos 
in our ow experionces and that of others which resutos it conclusively. This is not a confossion of verknoss but enothor way of saying that wo Ero human beinge with human virtues and weaknosses. It socms that horo is the place for the teacher to rorget about environment and stimuli and, in an active rolo, through the modiun of tho telling mothod, got the idoe acosss to the chilaren that whatover they thing about thoir own possibilitios it is essontial that thoy mastor tho matorial at hand. If it isn't worth mastoring wing jive it at all? Surely there is onough subjoct-mattor worth rnowing, in fact ossontial, forthe woll-boing of tho avorage intelligont porson, to koop hin busy in school. The mothod nooun't bo authoritative attor tho mamer of a top sergent spoaking to his troop, but it is nocossery to explein airectly that thore are cortain things that nust bo done, cortain onds thet must bo accompliched. Where must be 2 vell deflnod eround vork of information. Othervico how is tho indivianal soing to dotormine whet his possibilitios aro?

It is only through a knowlodre of ossontial facts that wo aro able to be critical and copo vith materiol snd spiritral concopts which come to our attention delly. There is nothing in Dowoy's philosophy of oducetion which provides for a dofinito assinilotion of a definito body of information. Until ho embodios that principlo and pleces less faith on the indiviaual child's ability to unfola hinsolf in such a way os to gain that body of information by lenaing his onersios 
to the posgibilities, Dowoy will bo opon to profossor Kandel's critiocl obsorvation thet progresuivo educetorg "hovo rolied in the megic of growth, self-exprossion and dovolopmont from within" and Hicholas liurray Butlor's comont comparing tho child to the cow, Iazily grazing in tho pesture, evting wht plouses tho ojo and whet nay fill tho stomach.

In conclusion. Dr. Dowey's oducation is basod on tho following princlples:

1. Socializod inctruction in which all mombors of the group cooperato by contributing to the group.

2. Ixporinontal tosching in which tho toocher has tho role of an obsorvor, inspiriug and widing.

3. Proo schools in which the childron can work and find there natural sphore of ondoavor commensurate vith their copacitios and interost.

4. Involved in the third prineiple is tho principlo that the school chould roprosent tho social institutions of Iifo in thoir gimplipled or embryonic form.

5. Progross of the individual from ono top to tho noxt at the rate of tho wholo group with froodom for tho inaividual to master the work at hand up to the linit of its possibilitios.

Recont axporimonts in curriculum miline at Vinnotica.

Carleton Vashburne at Winnotka, Nllinois, has dono considorablo worls to detornine what the school subjocts should bo and hov much of oach subjoct should bo tausint. 
Beforo discussing this phase of his work, howevor, it is ossential that wo know some of the fundemental prinoiples of his pedagogy.

First, ho is a followor of Dr. Montoscorl in that ho is an exponent of individuclized torching, However, inetead of devoting his intoreats to an inaiviaualizod from of instruction basod on the biological seionces, he has conducted a number of oxporimonts in currioulum making.

"rithe course of study in nost Amoricen public schoole is the rosult of trodition and guose vork. Somo features of $1 t$ aro usoful and nocossary. Somo aro absolutely worthloss. And somo aro actually harminl." (50)

Thus he aums up his indictmont of tho traditional school curriculum. It is afficult to criticizo or defond his position because of the lack of conclusivo proof in oither direction. Tho problem is extremoly controversel. For every person who beliover that algobra is a useless subjoct to be tausht, wo can probably find anothor person who would ploce it at the top of the list of school subjecte in oroder of morit. Both would undoubtody bo ablo to prove his position by referring to specific oesos and tho usual deadock would result. Accordingly, Naghburno's viewpoint is important only in so far as wo know that it is his viowpolnt.

He goos on to sey that "the leading progressivo school systoms are almost without oxcoption feeling around to find out which of the so-called common essentials of knowlodge-- 
frequentiy classiflod as "the throe Rs"--should bo taught, and how much proplcioncy should bo acquirod in them." (50)

As shall bo pointod out subsequentiy, his mothod of solving this problem is, in somo instonces, interesting and unique.

Second, It is woll to point out that the fundamental stops in Washburno's individualizod tocching procoduro aro porfectIy consistent with his attitudo towards the curriculum. Thoso stops are:

1. Individualizod toaching roquiros the tocchor or group of toachers to set down in black and wito e.ecty what it is that thoy oxpect ovory child to mastor.

2. Thoro must bo comploto, aiagnostic tosts to covor tho objectivos the tocchor has spec1fiod. (51)

Obviously, before tho toachor can say definitoly what ho oxpects the child to master, he must lnow exactly what those things are himself. Whe dofinitonoss of purposo horo is commondable and is exacty tho thins that is missing in Dr. Dewoy's philosophy. Washburno ovidently roalizos that there are "common essontials" which are absolutely nocessary to the individual if ho is to be usoful citizen in socioty. His only concern is thet those ossontidls bo set out and defined in thoir propor rolations and proportions.

"For the first ti 10 in the history of oducation vio are 
facing aquarely a tromendously important fact; Wo don't roaIII inow What childron should bo tausht."

What contitutes problom-solvins avility in arithmotic? Hov much oi it is neodod? How can it be tgught? What use is geonotry? That perts, if any, of algebra aro of value? Is the value of Iatin suficiont to justily tho timo it requiros?"(5z)

Inose are some of the probloms he has tried to solvo. Lot us exmine some of his oxperimonte in this direction.

In "Better schools" ho tolle about one of the eerly rosearchos at Vinnotize. "In erithmotic, obviousiy, chilaron should be taught to ad, subtract, mitiply, and aivide. But how repialy should they bo ablo to do this? What dogree of acuracy should be royuired of thon? Thore had beon, Et the tiue the Winnetira work comonced, no investigetions which throw cloar light on these questions.

"It is true thet somo atudies had boe mado of the kinds of arithnotic usod by pooplo in their deily lifo. Lvery child in a cortain school systmo had beon salcod to have his peronts te11 him each day what sort of arithmetic they had to uso in their work..... Anothor study hed boen mede of dopertmont store ond hardware store sales slips...... study had been mado in factorios where piece warl wes done as to tino arithmetic that was nooded by tho workers in ordor to dotormino thoir wagos. All thoso jloldod como knowlodgo as to tho type of material tirat should wo teught if our childron aro to moot tho domends society will meke of thom. 
"But thoso studios did not provide nearly enovgh data to nake the goald of individusiizod work cloar end dofinite."

Wo must intorpret Washburno's menning here to bo that these studios, notivatod by utilitarian purpose, wore not broad onough to reach a dofinito conclugion. Consoquently, he sags a compltoe of superintondents and principals vas organizod to carry out on investigation on the "degreo of arithnetical spood and acouracy poseossed by intelligont and succosaful men and wonell." Tho idea we to got various civic organiations to tolio tests in school arithmotic, beginning with tho firet grado and progressing to tho point at which thoy oncountered difficulty or vere stoppod complotoly by tho problems.

"It bogan with such organiations as Rotary and Comnorcial olubs. Paront-Toechor esgociations woro leter addod in alotriots whero those reprosontod a rethor unusually high avality of intellicence and abllity. Membors of these organizations, all of thon prosumebIy? both succosstul and intelifgent, wore asked to take the semo tests that woro givon to childron in olomontsry arithmotic." (54)

Washburno ovidontly roalizes the ludicrousness of the situation by his froquont assertions that these pooplo vere o.11 intolligont and succossint. Also, his statomont that "parent-toachor associations wore lator addod in aistricts where those roprosonted a rutior unusually high quality of intelligence and abillty" voula load us to infer that ho did 
not hold the usual organiation of thet sort on the eame lovel with Rotary and Cormorois. Clubs and consoquontly it was neccecary to go to districts whore this group ropresentod an unusually high ordor of intelligenco and abllity. We aro lod to believe that ho valuos a Parent-Teachor Association in direct proportion to tho amount of material succoss attainod by 1ts individnal mombers. It is ovidont that he is attompting to orgenizo the curriculum in such a way that the things in arithmetic conducive to a succosstul businoss careor will bo taught. As a spccific exornplo ho tells about a well-todo Chicago businoss man taking a toat in arithmotic along sido a high school principlo. At first tho business man was solving tixe simple problens tuico as last as the principal. Then they came to frections, "tho principal went to work quickly, and aftor doing throe or four oxamplos glonced at the manufacturer's papor. Ho had triod tho first oxample threo timos and was still worlxing at it. When tiro was celled tho manufucturor had ony done ono oxample--and his answor to that was wrong:"

"This did not rollect or the menufacturer's intelligonco. It morely ghowed that schools wore putting far too much stross in placos obviously not much usod in life.

"Whon 011 the rosults wore tebulc tod it was found that tho Parent-Teachor Associations, Rotary, and Commorcial Clubs alike did about as woll with thoir eractions as tho avorago fifth grado child, who is still just learning the procoss. 
"Ihis geve a definfte cue as to whero omphasis is neoded in tine schoolg." (55)

Tho sume utilitarian motivo was followed in othor school subjocts. In apolling an invostigation of poriodicels, books, business letters, student compositions, and so on vas conductod to detemino tho vords used most freguontiy.

"A spollor containing 4,000 words should obviously includo tho 4,000 commonost words in tho langrage. Evory child should know how to epoli such words as poor, power, poroont, pretty, put, quick, mn, rise, roech, end reason, which ero enong tho 1,000 commonest vorỏs in the Inglich Ianguge.

"On tho other hand, such words es dofelcation, moritotious, gratutious, oncuribranco, and accendency aro so littlo used as not to fustify tooching thom at al1." (56)

In history and googrephy a suivey wes mede of poriodicals ond newspapers, in tho scre menner, to determino tho rolativo Prouluency of factusl allusions in this connoction. Those most froquontiy usod wore the onos to vo Iourned.

It is obvious that Vaghburno's notivo is ontiroly vitilitarian. In other wards iro bolioves thut tho cliza should be givon only the baio ossontials (and lots of treining in those) that heve to do with our evory day economic existenco. Suppose wo trainod our doctors in that way. Suppose ve mado a survoy of the nost important aisesses and then ratiod thom in the ordor of their froquency. Supposo we found that thoro aro a number of afsoasos which aro roletively rero. 
According to Washburno's idoe, we world throw thoso out as uniraportant and train our doctors in the moro important onos, that is, the ones which occur most frequontIy. The rosult world bo so obvious that it does not require more elaboration hero.

The comparison holds. Wo have a mass af chilaren in our schoold with differing interosts. They erow into adulthood and go into ovory conculvable kind of occupetion and profossion. Thus, in ordor to give equal opportunity to all, we cannot dotormino what our school curriculum shall be by finding out what succossful morchants and business exocutives nood in their ovory day existenco.

If we accopt Washburno's utilitarian viowpoint, we muct throw out the cultural values of education. Unfortunately, perhaps, those valuog aro of an intangiblo naturo and consoquontly sro not as suscoptible to oxact moasurement as matorial valuos aon to bo. Thero are \& fow pooplo, howevor, who plece some value on them in the school curriculun.

Bomard Iddings Boll, Vardon at Saint stophons Collogo writos a scathing article ontitiod "Private Thoushts of a pedegogne" in tho Jenuary 1935 "Tho Amoricen Scholar." (57) Ho says in paxt:

"Ihoro are not meny oducators who beliovo thet 'mathematics as rolatod to IIfo' is as good for tho human mind as analytic soomotry or calculus. Of course not. They morely know, from aed trial, that the great mass of stradonts dumped 
on then becauso of comprleory olucation lavs..... is mostly comosod of poople with only brejns onouth to comprohend piffing gubjocts, and that with difficulty. Thoy are forced to hand out high school diploms.s to students who cennot do a single inteliectuel task."

Is this tho notive bohind. Meshburno's apperont attompt to mako "p1ffling" subjocts out of tho ordinsry school subjects th "innotira? Whothor ho bolloves so or not, wo must accume that ho is sincoro in trying to adapt his school subjects to 11 fo. Boll'g rofereno to "mothomatics se rolatod to lifo" $1 \mathrm{e}$ obviously a diroct lit at tho novomont in projroseivo oducation to minimize the value of school subjects, at tho utiliturian motive which forogoos any knowlodeo other tien that which ney aid us to make an honost and stidifactory living.

His reforonce to anrlytic goometry and calculus loads te to beliove that Boll belioves that these subjocts have some value in montal training. It may bo that, if whon science puts cultural valuos on a mathomatical bosis, a woll trainod mind in tho puro scionces and cultural subjects vill bo somo valuo, at loast in rogard to such intangibles as cultural bookground and poiso.

Tho Himnotra systorn of individualizod tosohing. Ono of tho fundamontel principlos of Weshburne's podagost is that oach child shall prouress at his orm rato. This imiles a toaching rothod which is practically tutotial in the each child is treatod individually. Individuol assignents are 
given whon the last one has boon complotod. This principle is based on exporinonts thich has show "that elnost any Iourth grado contains childron of socond, third, fourth, filth, and gixth grad ability." (59) Nachburno boliovos that in order to oqualize this rang of ability evory child met be allowad to mastor "oach unit of his work boforo he goos on to tho next undt, without boing held back by slower chilaren or forced forward by factor onos too rapidy for mactory." (50)

Ho belleves thie method is adapteblo to tho "oomon ossontials--tho throo Rg"-Thoro is no othor wey gottinc widely difforing chliaren to attain a oomon standard. "But thoso subjocts in which childron may logitinotoly differ, or whoro wo vant to capitalize on thoir difforence, may bo socialized-wo classify thoso es group and crestive activitios. (60)

Hero Nashburno outiines cloerly tho point at which ho diffors vith Dowoy. Whilo Dowoy bolioves that all sohool subjects should bo socializod, Teshburno beliovos thet subjocts such we arithotic, spolins, formel Englich, history, and goosraphy, must bo gotton by tho child dirocty, definitoly, and conclusiroly and the motiod he chooses is the individual. Thero aro sovorul adventagos in favor of tho individualised mothod of instruction:

1. It allows tho chila to go alone at his own rato. Ihis is fevorablo, of courso, to tho bright chila becauso it koops him busy. Theorotically, at losst, ho alveys has somothing before him. Ihe dengor at vinnotla is 
that tho curricuIum wiIl bo eut down to the extont that ho nay not havo to go boyona iractions or lorra to spoll words othor than those that any fifth or sizth grado child can grell.

2. Tho pupil concontratog this attontion on his own individual advancomont and does not fudgo his progross by tho averago of the eless. This 1doe is liable not to work out in practice since tho chilaron are normolly in the hobit of chocking with one anothor as to their relative progross. For instence, tho guostionof moment when roport cards are isgued is: "What did you cet?"

3. A spirit of competitive action is likely to result with a rosulting imcontivo to work. This applios to bright chilaron ordinarily. It is not inconsigtent with the socond point since some chilaron have the compotitive spirit and somo do not.

4. It prevonts the illusion of making progrosg when it is not mado. Inder the Ninnotira syotom of giving teets at the ond of oach as ismont, this is particularly true.

5. It tonas th oliminate idlonoss and tho rosulting 10 y habits. It also tonas to olininato a feoling of falso sitiefaction arons the brightor students. Thoso are montal habits wich ofton dovolop among the brichtor studonts in tho schools using only group instruction. 6. It dovolops individus initiativo by not roquiring the 


\section{1}

any child bo held to tho lovel of tho group.

7. It permits the glov child to progress at his oum rete and thus permits thoroughnoss.

8. It prevonts an individual boing carried clong by tho group. In other word indiviaualized educution in ita idoal form would provent an inaividual from goingboyond his capaoity in any suijoct.

Thore are also a nurabor of disadventeges in regard to an individuelized notinod of instruction.

1. It forgoos the advantages of traininj in cooperation. At Winnotka, howover, socialized oducation is an escontial part of ovey dey instruction.

2. Economic wn poljtical foroos may tond to disrupt the procoduro of individusizad instruction. That is, the finances of many towns aro such thot thoy insist upon the child boing promoted overy yoar, in othors overy two Jours. For instance, during ivayor Thompson's rogino at Chicaso tho suporintondont of schools was dismissed bocause ho insistod thet the child should not be promoted until ho morritod it. Ho ves aicnissod in the intorest of cconomy. Iurthormore, with our more or loss acourato idoa that mas production promotos losser individual costs, it rould soom that on individualizod from of instruction would groaty increase toacher and elassroon costa.

consistcht with tho general 1doe erone progressivo oduce- 
tore, thore ia no system of gradins et vinnotka as wo know it in our publio schoold.

"Since individual. work reguires each child to roach "one hundrod por cont" on each unit, the ordinary roport cord vould be moaninglosa..... So inctoad of giving glados we givo dates-the datos on wich tho children havo completod oach test in each subjoct. For thjs purpose oach child hos a goal carả on which all the tosts or work units for two grades aro listod in parallol vertical columa." (62)

Mhose goal carde contrin tho wits of esch courso in thoir propor sequenco. The cinld has ono to koop in his dosir and tho teachor has a composito card for the class. Whon tho chjld has finished a unit of work, ho soos to the toacher and takes a tost. If ho hes mastorod it, the toacher wites in the dato opposite the unit on the child's cerd. Fe elso meiros a note of tho anto on his own card. In thet way the toschor cin soe at alence whore each child is and can holp or stimuleto in somo way tho lagsins mombers of the class into activity. Socialized ingtruction at Winnotka.

"Tho sroup and creativo activities aro vital Iife-jiving nert of tho curriculum. Whoy aro tho real aducation....(65) The eroup and creativo activitios jncluae alscussions, but those are discussions of dobatable subjects, not recitations an 109 sons 0.11 childron have studiod... Theso setivitios rney include organizod playsround work, clubs, comnittoes, and. solf-govornment. Thoy mey include a school nomapapor: and $\theta$ 
school bazax. Ihoy vill aIwerg incluả croative exprossion through art, handwork, and informol English composition."

Thus Weshburno statos his postion roerding tho placo of the social and creativo activitios. Ihoy aro the roal education. It gooms that is he cuts down his curriculum in the ray ho has sugrested, he will have lots of time for tho social and croutivo activities.

It is too soon to got any accurato data as to the rosulting vulues of the so-callod. "Irills" of education but some obsorvore iw vo ventured an opinion. Hor instanco, Boll seys thet porhaps that is what the children want, and since most of them have not tho bruins suscoptiblo to disciplino or training it might be just as weIl.

"Very fov educotors believo, for oxamplo, that froodom for students to do as they ploase is bottor than disciplino, but they do know erom precticel exporience thet nogt of the students, not having any brains to to aisciplined aro happiost and croate loast troublo when Ixeo Irom its restraint." (65)

\section{IHIT DALTON DIAI.}

In "Bottor Schoolg", Tashburne says:

"In somo weys tho prinoiple involvod in the "Dalton wan" is closo to that of Individual nechnique. Just as w th tho Individur rechniquo, the rumamontal aim is to allow oach child to proceod at his natural gait, whilo tho onpinesis lacod go hosvily on rocitation hours is lightonod. Under tho Dalton rlan, it a studont has not fintisod his assignnont in tho fivon 


\section{4}

wook or month ho can take mort 1mo to do it. If ho has finishod ahead of timo in all subjocts, ho may co the next month's job. Individunc prosiess is posaiblo." (66)

Spocifically and in outino from the Dalton 1'lan is this:

1. The work of tho yoar is dividod into and laid out in monthly form. At the beginning of the tom the studont is givon his monthly assignnenti for erch subject. As soon us all monthly assignnonts aro completod, a nov sot is pivon. In tho assignments are includod dotailod information rogarding topics, probloms, ororoisos, weitton work, roforoncos, monory work, and standards.

2. Whoro aro 110 rocitetions as such. Instocd thoro aro laboratorios to which tho pupils so whonover thoy vish. Those laboratorios aro under the suporvision of tocchers wio aid the pupils in thoir assignnonts. Tho prosros: of tho childron is kept on rocord cords as modo. (67) Ihis, briofly, is the Dalton 110n. It will bo notod in reading tho first point that it differg with tho Individuol sy. tom at Hinmetia at two points:

1. The Dalton rlan assijuments are a nonth in lengtin vile thoso at Winnotre covor oach atop in a subjeot.

2. Tho Dalton Plan provides thet agsignmonts in 011 subjocts be completed before novin on to the noxt set of assignmonts. At Winnotra, the pupil projrescos in each individual subjoct as ho complotos orch essignment. Thus, in arithmotio, ho may bo a month or noro 
in advance of his progross in spoling.

In the first instanco tho Vinnotia pien is porhaps superior to the Dalton Plan. The groat najority of tho chilaren in tho schools, at lodst as it worked out at Delton, prasachusotte, apparentiy cannot copo with Iong tom aseignments. A month to a youngstier, is a long, long time and conseguonty ho is liablo to bocomo lax and indolent undor the falso assumption that there ia plenty of timo.

Regarding the socond instance thore is no roal besis for choosing botweon the two. Io one hes proven conclusivoly why the pupil should progross at tho sane spoed in all subjocta. phose who Ilire conformity will laen tovard the Dalton Plen but apperonty it is wholly a mattor of opinion based on personal preforence.

Regarding the lack of rocitation poriods and tho froedon of tho chila to go from laboratory to laboratory at will, the samo criticism applies as in the caso of the podegosy of Drs. Montoscoxi and Dovey, i.o. tho "freodom" is liablo to doterioroto into ainloss wandering, hale hourtod study or attontion to petty things which aro of no particular veluo. Ho is liablo, as Dr. Butlor puts it, "to oat what pleasos tho oye or is apt to I1I1 the stomach."

The chiof adventace of tho Dalton plan is, if it vorks, that is bound to develop initiotive and exorciso the talent for rosearch. It is obvious, hovover, that this would apply to the good scholar nor often then to tho poor ono. Thus tho 
criticism horo is diroctiy opposito to that of tho ordinary public gchool. The usual advorso cirtloism of tho public school Is that it tends to dovelop bad montal habits in the bright pupils, those of indolance, and dovolop a pooling of felse satisfaction, becauso tho pace is too slow. Under tho Dalton ulan the bright and industrious pupil has the advantoge wilo tho far groater number of average and undor avorego pupils havo too much of an opportunity to bocome irrosponaiblo and lag bohind. Practical intorprotations of Progressive Principlos.

Out of those various doctrines and plons havo onorged scores of the so-callod progrossive schools throughout the country, in fact, throughout tho world. They are mostly of a private nature but a fow tovms hove an elonentary gystem of public schools baged on progrossivo prinoinlos. Vinwotta, Illinois, Bronsville, How York, and Gerdon City, Jow York are the outstending onos. It is interesting to note that, in ecch caso, the town are roltively woalthy rosidontial subusbs of laI, oitios, Chioago and Now York.

In Gonoral, tho progrossive schools vary in charactor and mothod from tho loosost sort of monstrosity to those with well dofinod curriculur and objectivos and close supervision. An oxamplo of tho firgt might voly bo tho opoll Air School in Florida. An oxmulo of the lattor is the prosregsivo school at G111 HaIl in Northaxpton, IHas sachusetts.

The Opon Alx Sohool in Forida has intorprotoa John Dewey , it soong, a Ittlo too litoraly. Whilo conversing with a 
Pormor teachor $(68)$ et this school, it devoloped that the open Air School hal takon Dowoy at lis faco valuo on his atetement that tho social institutions aro tho bases of 0.11 loorning. For instenco, during ono torm all subjocts radicted from tho horso a a social ingtitution. Arlimetic consisted of ading tho numbor of logs to tho mumbor of ears and nul.tiplying the number of oyos by the nunibor of tails. Coography consistod of studyins tho naturel habitats of tho horso. Finglish consistod of vriting tromos doout the horse. The methou of atuaying amorican history was not discussod but porhaps thoy bosen vith Panz Rovoro's Ride:

It is obvious thet o condition of this wind is lot worthy of discussion except to indicato the longth to which progrescivo schools havo orortod thomsolvos.

un the othor hand tho progressivo school at Gill Hall in Iorthompton, Fissachusotts is a nore rational sort of oducational institution. Tho principel (69) was vory careful to nako closr, in coply to a quary, that his school would bo considerod es VAry corrsorvative.

In the first place, thero vas a curriculun, doilnito, cloar und witton down. Specifiod poriods of tho time woro noted for each subjects. The subjocts, thoracoivos wero inaicatod by names as usod in our public schools. There ves ono excoption. Geosraphy and History wore missine. Upon inquiry st vas lowrnod that the name of social studies mes usod instead. It sooms thet most Irogrossivo schoole havo combined thoso subjects 


\section{8}

Into one another. "Tho social studios in Vinnetke comprise history, geography, civies and somo ocononios."

Whore is a definito gdvantage in this procodure. It is this: the pure menory procoss of loarning countrios for instenco and their rolativo lacations 19 ably supplonontod by assoclating thom with instances occuring vithin them. Also, In possing, it is intorosting to noto that the idea fits in with Washburno's underlyine principlo concomning tho curriculum i.e. Who information nost PrequentIJ usod in I1fo id the information to bo loarned. Thaso locations in the worla which have had tho nost to do rith the cultural advancenont of the world vill receive the most sttention. uutlyins regions will rocelve soent attontion nocessarily. Fronch and Iatin are included in the curxiculum for seventh and eighth gredo chilaren at oll1 Hall. This is one of the minor inovations instituted in some of the progrescive gchools. The stray ia lintroductory and of courso vory simplo in character. other than fiving tho childron a head start when they como into compotition in tho public high school vith othor childron, there is no real necossity for introducing theso subjocts so arily. With this curriculum it is obvious that freodom amone tho childron is rostricted of nocoseity. Concontration is roquired to get ovor tho specific hurdes set up. As fer as possiblo howevor, tino children ere frec to nove about as they wish.

As indicatod proviously, tho classroom atmosphore is de- 
cidodi.y prograss17o. Uutsido of that sne tho rectrictod froedom os the childron it is aiffenct to soo enything of Montoscori or Dowoy in this school. Tho dofinito curriculura rominds ono of Tachburno but it is also rominiscent of tho public gchool curriculum. The combination of higtory End seosraphy into one subjoct and the introduction of Fronch and wetin aro tho only oscontial points at wich this currievlum affere with the pulblic school curriculum.

In botween theso two gchools thoro is k. wido range of progrose1ve schools which aro corrging on in a quict ond unassumins maner. Unless ono visitg these schools, ho finds it difficult to got ony information about thom bocauso of tho lick of such information coning from then.

What, thon, has exnsod this wide diveraity in mothod anong the indridual progrossivo schools? It wovld coom thet thoro aro tro important roasong for 1 t.

1. Leck of agroenent among tho foromost vocel and practical expononts of tho novement.

2. Tho abstract, wad oftentines vegue, Ijtorexy stylo of John Deway.

As aroady pointed out thoro is considorable dicagreemont anong the liontessori, Dowoy, "Washburne, and varkhurst. whoir undorlying principlos vary at soveral vital points and, at times, whon thoy soom to agroo on the surfuco, it hes boen shown that the have diffored in their objectivos. It is obvious, thon that individual o ucutars aosiring to institute 
progroseive principles in their schools havo had two porhaps throo alternativos.

1. Thoy could soleot tho oducational philosophy of ono op those poople and follow it implicitel 7 .

2. They could seloct thet, in their opinion, woro the beet perts of orch and combino them.

3. In adition to (2), they could add their om idea based on thoir own oxporionce.

It is obvious, then, thet the difforing viowpoints of the rocognizod leadorg in veogrossive education hevo rosultod in a wide assortment of mothods used in rrogreasive schools.

DaweJ's abstract and somotinos vague mannor of expreseing himself haa tondod, porhaps, also to hare extondod this djrorsity of mothod.

i) Dr. Clande H. Fuoss in his article "riho Promise of rrogresıivo iducation" in tho April 1953 "Current History" says in part:

"Profossor Dowey's "Mig leargosic Creed"....is \& documont of extroxdinary vaguenose, rich in phrases whoso sonorousness aoos not explain thoir oluscurity. of what prectical vaIuo is it to on instructor in the Utica Ireo Acadomy to bo told by Dowcy: 'I Deliovo that oducetion must bo concoived as a. continuing roconstruction of oxperionco; that the procoss and tho goal of education are the same thing' or to road this puraling sontonce, "I believo that the subjoct-matter of tho school curriculum shovid mark a sradual difforentiation out of 
the prinzitivo unconscious unity of sociul Iifo." This sounds wo11, but to most roedorg it neans nothing.

"Tho tokchor vants to know whet to do. Hrofoccor Dowoy, stimulating though he is, rosponde with idoes, al which only tho ear extrect $\&$ voriablo schomo. I have fornd that many articlog oil nrogroseive education toll mo quite cloerly what is wrong. But I know mysale what is wong. What they do not always do is to outiline a policy or a mothod which will put good pormenontiy in the placo of evil." This vegucnoss on the part of Doway has, no doubt, resulted in s varioty of inaividus interprotations, rosulting in further divorsity of mothod.

\section{Tho intorost "burberz"}

If wo interprot tio genoral progrossive school idoo literally regerding oxtronoous notivation wo must arrivo at the conclusion that all interest stimulation must como from within the chool subjocts themselvos. Hrines and punf shmonts must not be usod. Dowey goos as far as to vay thet tho interosts of tho child must neithor bo humored or iopressed. ("70)

Becauso of this primeiples, procrosstro tochors havo roverted to a number of mothods on the chance they micht be oonducivo to stimulatins intorost. rinis necossity has had a tendency to furthor axtond diversity of motinod anong prosrossivo school

Botoro going into a discussion of somo of these mothods or vohiclos for tho purposo of stimulatingintorost, thero is 


\section{2}

an acsumption in tho principlo underlying the nrogrossivo school intorost filoa, which must bo analyzod. It is thir: ixtranoous motivation is alvays bed bocause it londs a suporfloiality to loarning wich oventually results in a logs op true educationol velues.

A specilic instanco comos to mind in wich a student, matriculating at this colloge, was told by his fathor that if he flunkod one subject ho would wo imnodiately witharuvn from colloge, whis studont vont on to bo honored by boins ofiered a mombership in thi Kappe Fhi. obviousiy this inoidont proves nothins. It opons tho wey mereid to an ondless controvorsy. It is reforred to simply to indiceto that extreneous motivition has boen offective at times.

It aocms that in the locrning proooss, narticularly whon tholo is somo dofinite body of metorial which must bo loarnod, thet thare is room ror both nothods. It is obvious that the prosressive school method is the nore idoalistic ono and shoula bo resortod to first alwes, but, like most idcals sinco It is diffoult of attainnant at timos, it scems that matorialistic earthy mothods are bottor then none at 0.11.

After all, a good part of our livos $1 \mathrm{~s}$ a rocult op consoluences. Bofore wo embark on a nev work, journey or what not, vo usuelly consider the onds or results which are 11 ablo to oventuato. Ho doubt the weitor, before preparins this paper, considerod thom. Sometimos thoy are contained within the projoct itself. Ihat would soom to be the idecl situs- 
tion. Un the other hadn, tho projoct night bo used nerely a vohiclo for attaining somothing onticely forolgn to 1 t. Ihis is the prectical situation. In life wo havo both. Then why not

in the school?

110thods unsod to stirnulato interest.

As indicutod previously, the Delton rlan was born in mies Parkinust' misd ot tho tino when she wes boginning hor oducational carogr--in a mural school. Hor problom was to teach ono cless and roop acvon other classos interostod in thoir studios.

As indicatce beforo, John Devoy's whole philosophy of uduation rovolved about the natural intorests of tho child. As also inaicatod boforo, the mochanisms chosen by the numorous pHogresgive schools to bo tho environment to which chila intorost is to resnond has resultod in a lergo varioty of mothods. Thore is ore wethod, howovor which hes proven suecessful and erfoctivo. It is also boing usoe in our rublic schools to day, havin; beon token over from the procressive school moroment. It is the "project method."

Briefly and by concrote exanplo, the projoct method is this: Tho subject history. The poriod is the "lidalo Agos". Tho period is divided into broed divisions such s.s "Foudalism," "riho Church," "Invontion," "ihe Comm reial Revolation" and so on. "Foudalisn" is dividod into projoct cubjocts auch as "Costlos", "Sorf," and "Country lifo." "riho uhurch" is divided in "Rollefe", Orencization," "tho rucaling Friers," "Cothedrals", "The Hirst Crusades." Each broad division is 
studiod soparatoly. A projoct subjoct is assignod to erch moxisos of the clase. A bibliography goos with tho essignmont. Who chilaron thon proceod to look up tho matorial for thoir aubjoct, write it aovn and read. it before the class when they arre crIIed.

There are a numbor of docidody advantagoous aspocte with regara to this procodure:

1. It ororcisog tho faculty for olomentery rosorch.

2. Tho respongibility is on tho studont.

3. Indolenco and lazinoss is brought out into the opon enrt osposod.

4. The bright ond induetrious studont is not hold beck by tho group.

Thore is one disedvantage in regard to this mothod. It is offective only in a fer school subjocte. It scems obvious that this mothod would not bo particularly adaptablo to aubjocts such as arithnotic, gramor and speling bocauso subjects of this tjpe are not sulted to division for the purpose of chilaron making individual exploretions in order to dump their results into tho comnon pot. Phoso aro rota momorysubjoots a difforontiatod from "gist" subjocts and ero mastoroa bost whon alI the students apply thonselvos to all the steps until thoy aro lormed. It worra not bo miso for inctence, to Uivo ach child a difforont group of vords to lesrn to spoll and thon expoet 011 tho childron to bnow how to spoll alI the woras eimply by having oach cilize rool off bofore the clase the 
words he has learned.

There are two dangers which must be avoided in applying the project methods.

1. Each project should be a unit in itself. in other vords there should be a well rounded idea contained within each project which may be developed and worked out. utherwise the child will have an inderinite objective which will usually result in loss of interest or a tendency to roam into fields not intended.

2. Closely related to the first point is the necessity of making each project big enough so that it will challenge and not so big that it will discourage the child. Interesting textboors.

In line with the seneral attempt to make schoolwork more interesting, much experimenting has been carried on with the object in view of trying to make text-books more interesting. Judging from the following quotation from "Better schools" it is apparent that a great deal has been accomplished in this direction.

"One spring the seventh and eighth grade children in Wimetka had a banquet for the bcisketball team. Linthusiasm ran high, and cheors vere given for the basketball stars, the athletic coach and popular teachers. suddenly one of the boys proposed more rahs for Rugg. They were given Iustily:

"It must have been about the first time that chilaren have ever spontaneously cheered the author of a text-book:" (7I) 
Washburne is obviously correct. But why e.11 this seoming outhusiasm?

Iuxola RugG of Columbia has devoted considerable effort to revising the fornel sohool tertbook into one more intorostLug, simplor and in its phraseology moro concistant with tho vocabulary of the avorago child. Ho "has boon ongacod Ior yoars in ...... Invastication thet hes had for its objoct tho tccohing of thoso facte end punciplos in history, goography, conomics and oivico nocescary for an intelijgent attack upon tho probloms confronting Mnorican citizons today." (72)

"gor exanple heso is a paragraph fron \& good orainary toxt:

Whe northern mon wore lioutonic, like tho Lneglich; and Ilse the ancostors of tho Injlich, tioy wore grost piratos and soirovors. In the timo of charlomabre thoy began to swarm forth from their northora homos and over run eII wastorn Duropo. In Frances, aster ropeated attaoks tinroughout tho ninth contury, thoy at leat sottlod dorm in a large district about tho mouth of tho hivor soino, wich wes givan thom by tho nronch

"And hore is the equivilent from the work dono in Winnotira as tho rosult of.....inrostigations:

- Onco in a wh10, Noxccnon mado lons tracing vojases to our countrios. Fiost of tho tine thoy woro just piretos. in the spring-tino thoy hazlod thoir long boats out of tho wintor-shods, and launchod thom in the wators af the narrow bays. whoy loadod tho ships with food and fichting men, and 
away they ariled. Sonotime one ship sont alone, but more afton thoy wont in Iloots of ton or twonty chipe, all eciling togrother otc."

"Who difference in simplicity of lengnego, and intorost is evinont." (75)

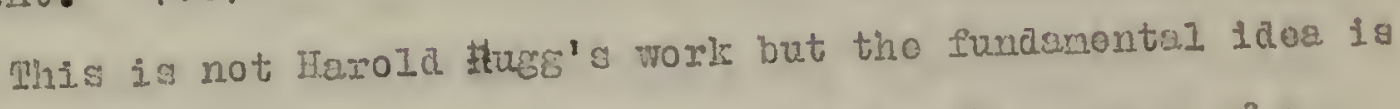
the sane as his, Simplo construction after the manor of a child's story book secms to be the objoot.

As lons as tho ossontial information is includod, there is no real roason why this from of tortbook woula not bo efroctivo. The idea underlying it soons rationel since tho stylo is ainilar to tho stylo of tho books tho chid rosds and consoquentiy with wich ho is Iemiliar. Tho mothod of loaming is important only ingo frer as it is offoctive. 


\section{COICIUSIOIH.}

Tho forogoins alscussion considorod tho philosophical background for the current movemant of progroseive education. It was pointed out that such ronownod thinkore $\varepsilon s$ Rabele1s, Iontaigno, Rousseau and regtaloami found ossontially tho samo things wrong with education in their day thet Progroseivo oducators find today.

It considored the dovelonnent of the progrossite education novonont and 1 tr prosont proportions. It was pointed. out that the story of the novomont is essentially the story of a fow doninant porsonalities who sew thoir idoal and havo striven to attain 1t. The onormous world-wide scope of tho propressivo education movomont ve discussod in this connoction also.

Finaly, the oducational principles of haria Montegsori, John Dowoy, Helon Parkinurst and Carloton Washburno woro outlinod, compared and criticeliy oraminod. The diversity of nothod, anong individur progressivo schools, was pointod out and sono of the undorlyine roasons for this diversity disoussod. Last, some of tho mothods rood to stimieto interest wero pointed out and discusseâ.

It is ovident thut wo camot look to progrossivo oducation as a wholo as a panacea for our educational ills. It is ovidont, also. that wo mut walt until that timo whon and if progregstro oducation shall roach a highor dogreo of uniformity ruming through it. Thero is too much aisagrooment within tho 
movemont itsolf, as pointed out, to givo tho intorosted. onlookor a fooling of confidonco in it as a wholo. The united. movomont as ozernplified by the Now Eareation Followship holds out the hope that ovontually It wil lose ite froe-for-alIcharactor by coming to an agrooment on $\varepsilon$ fow dofinito princinlos. Wo must wait antil that time, it sooms, for any objectivo rosults morthy of mention.

In the mountime the various oxperinonts conducted by progrossivo oducatorg vith resard to curriculum naking and mothods conducivo to natural intorost stinulation w1ll bocr watching. Also thoir proyress with individuriluod tooching will bour closo scrutiny. Those aro aspocts of progressivo oducation which may bo valued in the light of moro or loss imnediato rosults.

It is comistul is progregsivo oducutors wil over convinoe mo:t pooplo thet the child whould follow his orn interests in school. It is also doubtful it close supervision in tho public schools will over bo roplaced by tho la1zzoz-falro philosophy of Dovey. Ihose aro aspocts of progrossive oducation which moy be undoubtediy disccrdod vithout furthor t'oucht.

It seoms that when oducetors in general roach tho conclucion that thoro 15 no singlo mothod wich may bo applied to all subjocts with uniformily satisfoctory results and thet thore 1 a a nothod which is particulaxiy adaptable to overy anject in the ourrtoulum, thon wo shall bo on our way to a porfoct syatom of education. In tho mentine, if progressive ed- 
ucation can show us arnothing in this alrection, of a dofinito and conclueivo nature, then it will not havo lived in vain. 


\section{Bioliography}

Books

Monroe, "Briof Courge in the History of Education."

The Mecmilian Company, Waw Yorle, $192 \%$.

Mashbumo, "Adjusting tho School to tho Chila."

Torle Book Company, Yonlere-on-Hudson, How Yoxl, 1952.

Nashburmo and Stearns, "Bettor schools."

Tho John Day Comnany, How Yort, 1928.

Dewey, "Denocrecy and Lducation."

Tho Iracmilan Compeny, IT York, 1916.

Ians, "Iducational Croods." Now York and Chicsgo, 1898.

Montaigne, "rseay on the Education of Chilaren."
G. P. Putnom'g Soms, Wew York and London.

Rouseser, "Misilio."

D. Appleton and Company, Now York, 1895.

Rabolais, "Gar vantua" Novroll idition.

Postallozzi, "How Gortrude Toachos her Childrun."
C. II. Rardeon, Syrouse, ITew Iork, 1898.

Solzer, Honhemott, and CronmolI, "Introduction To poaching." llorace F. Tomile, Most Chector, Penn., 1951.

Dougless, Mrodorn llothods in High School "loaching." Iloughton ififin Company, Boston, 1926 .

Iozrick, "Progressivo Liducotion."

ilvorside Preas, Combriago, 1925.

Join Dowoy and Irvelyn Dowey, "Schools of Tomorrow."

i. P. Dutton and Company, How York, 1915.

Nontes ort, whe llontescori liothod." Erodorick A. Stokes Compeny, How York, 1926.

Periodicals and Bulletins Pell, "Privatio Thoughts of a podagogno." 
Thess, "Promise of Progressivo Mancetion."

Curiont History, April, 1933.

Smith, "The Hontossori systen of earation."

U. S. Bureau of Education, Bullotin 1912, No. 17, Whole Nurabor 489.

\section{Roports}

The New Education Rollowship Report of Jeriod onding June, 1932, London.

Soventh Annual Roport of the Hassachusotta Boara of Education, Boston, 1843.

\section{Difsortation}

oHara, "The Limitations of the Educational Thoory of John Dowoy." Submittod to the faculty of Catholic Univorsity in partial fulfilment of requiroments for the Degree of Doctor of ihilosophy, Washington, 1929. 
Irotes

1. Washburno and stearns, "Better schools," pp. 3 and 4.

2. Vashburie, "Adjueting the school to the Chila," p. 1.

3. Dowey, "My Podagogical Crood," Iang's "Educational Creode," p. 11.

4. Monroe, "A Brief Course in the History of Eacation," p. 217 .

5. honroe, "A Brief Courso in the History of racation," pp. $217-218$.

6. Rabolais, "Gargantua," Chapter XXIII.

7. Rabelaia, "Gargantua," Chapter RXIII.

8. Hontaigne, "Essaj on the Education of Chilaren," pp. 2 F.

9. Montaigne, "Essay on the Education of Chilaren," pp. 21 and 22.

10. Roussean's Proface to "Emile."

11. Roussoau, "Emilo," Book Seconà.

12. Seventh Annual Roport of Horace Mann igsued in his capacity as Socrotay of the Boord of Education, 1843.

15. Myrock, George A., "Progressive Education," p. 5.

16. restallozi, "How Gertrude reachos Her Chilaron."

16. Ufficial Organ of the progressive Eaucation Association.

17. Rugg, "Child Centred School."

18. Mashburne and Stearns, "Bottor Schools," p. 252.

19. Smith, "The Jiontessori Systom of Educetion," United States Buroau of Education, Bulletin 1912, Io. 17. Thole Number $489, \mathrm{p} .7$.

20. Fontessor1, "Tho Montessor1 Hothod," p. 42.

21. Parichurst, "Education on the Dalton Plan," Chapter I.

23. Fuoss, "Ihe Promise of progressive Education," "Curront History," Apr11, 1933. 
24. The How Education Followship, Roport of the period January 1931-June 1932. (Rovisod Iovembor 1932).

25. Smith, "The Montessori System of Educetion." Unitea States Bureau of Education, Bulletin 1912, No. 17. Whole Number 489, pp. 6 and 7 .

26. Smith, "rhe llontegsor1 Systom of Education." Unitea states Buroa of Iducation, Bulletin 1912, No. 17. Thole IJumber 489, p.6.

27. Lontegsori, "The Montessori Mothod," p. I.

23. Hontessori, "The Nontessort liothod," D. 5.

29. Dowey, "Democracy and Educat1on," p. 357.

30. Montessor1, "The liontessori Method," p.4.

31. Nontessor1, "Tho lontessori llethod," p. ".

32. Montescori, "The Ilontessori lothod," pp. 8 and 9.

33. Lontessori, "The hontessori irethod,"D. 11.

34. Montessori, "The liontessori llothod," p. 15.

35. Montossori, "The Montossori lleuhod," pp. 16 and 17.

36. Gill Hall in Iorthampton, Massechusotts, an Mlexontary school operated on progressivo principles and in connoction with Smith College.

37. Montossori, "The liontessor1 Method," p. 20.

38. Montoscori, "The iiontessori liethod," pp. 81 and 82.

39. Nontessori, "The Montessori Nethod," p. 80.

40. Montessori, "The Ilontossori Lethod,"p. 23.

41. Montessori, "The Montossori llothod," p. 24.

43. OHara, "The Iimitations of the Eacational Theory of John Dewoy," A dissertation submitted to the Faculty of Philosophy of tho Catholic Univorsity of Anerica in partial fulinilment of the roquiroments for the dogroe of Doctor of Philosophy. pp. 96 and 97.

44. O'Hara, "The IImitations of the Educational Theory of John Dovey." A dissortation submitted to the Facuity 
of Philosophy of the Catholic University of America in partial fulfilimont of tho roquiroments for the degroe of Doctor of Philosophy, p. 47 .

45. Dowey, "Denocrcoy and iduction."

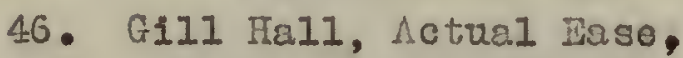

47. Selzer, Menhennett, and Cronwell, "Introduction to Touching, $" \mathrm{pp} .227$ and 228.

48. Dowey, "Democracy and Iducetion," p. 226.

49. Dowoy, "Sohools of Tomorrow," p. 139.

50. Washburio and Stoarns, "Bottor Schools," p. 131.

51. Mashburne, "Adjusting the School to the Child," pp. 3 and 4.

52. Washburno and stearns, "Bottor Schools," p. 132.

55. Mashburno and Stoarns, "Bettor Sohools,"pp. 140 and 141.

64. Toshburne and stearns, "Botter Schools," pp. 141 and 142.

55. Weshburns and stosrns, "Bottor Schools," pp. 142, 143 and 114.

56. "ashburne and stearns, "Bottor schools," p. 147.

5\%. Official organ of the thi Bota Lappa Society.

52. Vashourno, "Adjusting the school to the Chila," p. 1.

60. Nashburno, "Adjusting the school to tho Chila," p.2.

61. "ashiurne, "Adjusting the school to the Child," p. 164.

62. Nasiburne, "Adjusting the School to the Ch1ld."

63. Washburne, "Adjusting tho school to the Child," p.8.

64. Washburno, "Adjusting the school to the Child," pp. \& sad9.

65. Be11, "Private Thoughts of a redagogue," "American Scholar," Jamuary, 1933.

66. Tashburne and Stosrne, "Better Schools," pp. 288 s.nd 289.

67. Douglass, "Modern mothods in High School meaching," pD. 496 and 497 . 
68. Higs Robort, teacher of Iirench at Gill Hell.

69. Mr. Makoman, hoadmastor at Gill Hall.

70. Dowey, "My podagoglcal Creed," Iang's "Bducational Creeds, "D. 16.

71. Washburno and Stearns, "Botter Schools," pp. 153 and 154.

72. Washburno and stoarne, "Better Schoolø," D. 152.

75. Washburne and Stoarns, "Botter Sohools," pp. 151-152. 
Approved by:

Encoulex

charles F. Franker

$\frac{V . \text { A. Rice }}{\text { Graduate Commit tee }}$

pate June 8;33 

$\therefore \because$

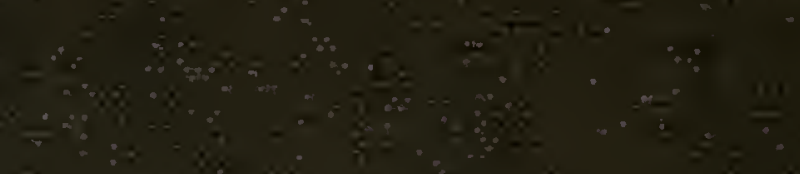

$\stackrel{+}{2}$

$\because \therefore$

30

and

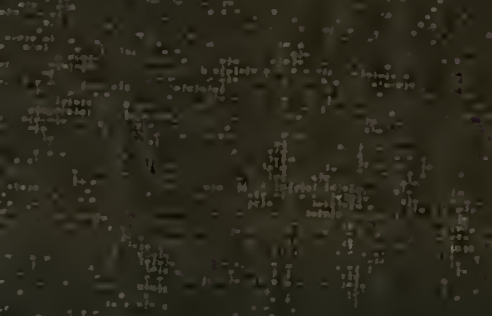

b.

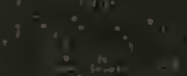

$\therefore+1,1$

$\because=\quad+18$, the

(5.)

? 